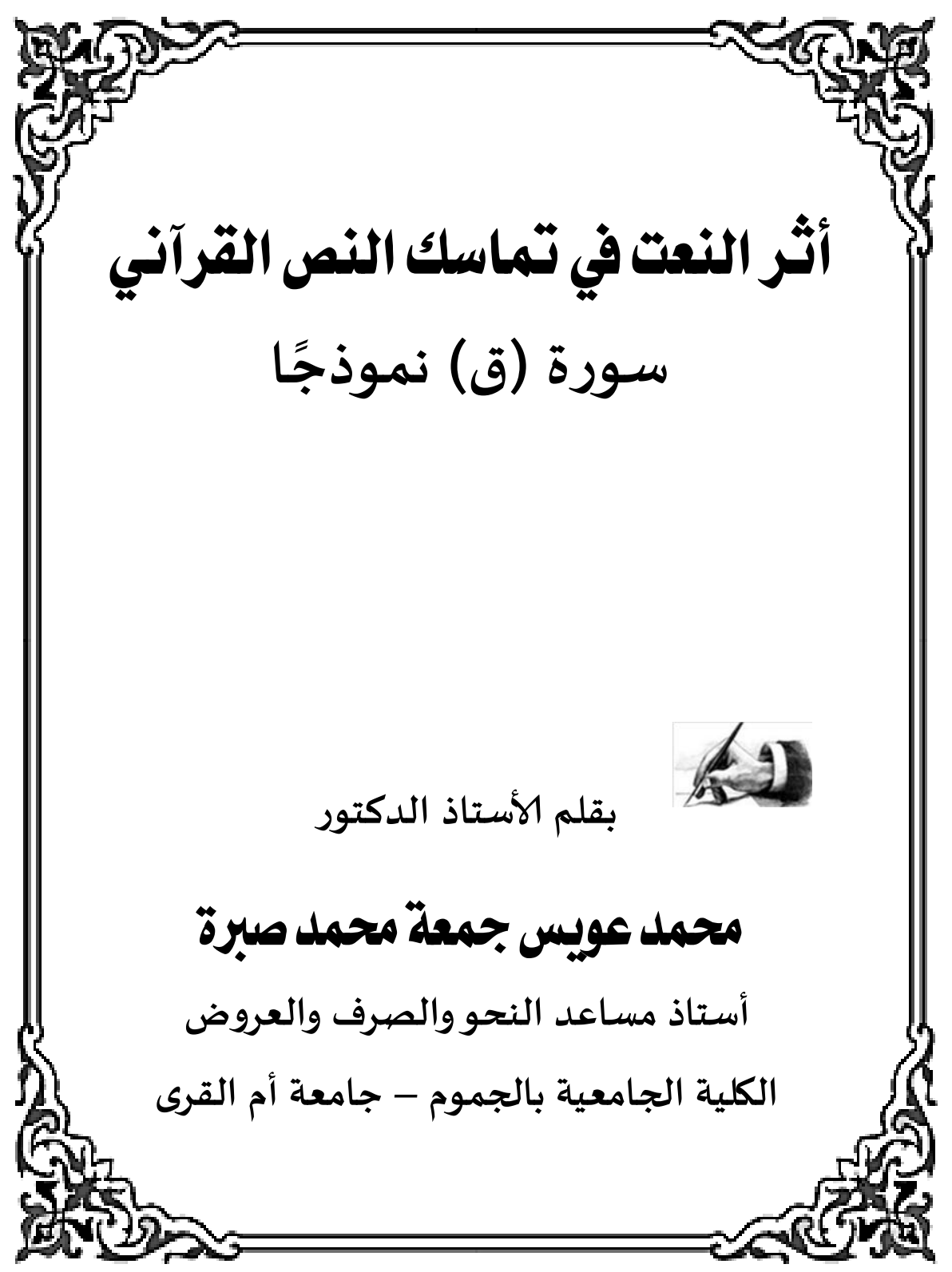





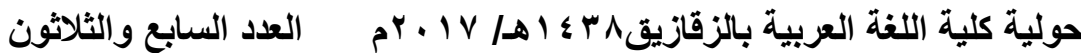

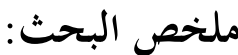

من خلال التطواف في ثنايا هذا البحث اتضح لي الآتي: 1 - كان للنعت دور أساس في التماسك النصي للقرآن الكريم كأحد أهم التوابع التي احتلت مساحة وافرة في النص القرآني بصفة عامة، وفي سورة) ق) بصفة خاصة.

فقد ضمت سورة (ق)وحدها ثلاثة وعشرين تركيباً نعتياً من بين عدد أياتا

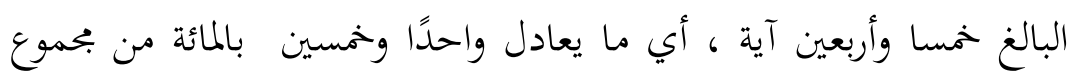
أياتها.

r- أن أثر النعت في النص يأتي عموما لتمام الفائدة والمراد ، وأن النحاة وضعوا أصولا عامة تحدد الدور الدلالي للنعت. ب- أن أهم دور يقوم به النعت في تماسك النص القرآني هو تتميم الفائدة الأساسية للجملة بمشاركة الخبر وغيره ع- من أهم الأسباب التي أدت إلى كثرة النعت في القرآن الكريم بصفة عامة ،

$$
\text { وفي سورة }
$$

( ق) بصفة خاصة، أن كثرة النعت تؤدي إلى إثارة انتباه المتلقي بما يلقى عليه من عموم النكرة ، ثم يحدد ويخصص هذا التنكير من خلال الصفات، وقد أسهمت هذه العلاقة في تماسك آيات سورة ا( ق ) وتشكيل دلالتها بصورة

$$
\text { واضحة. }
$$

ه - أن العلاقة بين النعت ومنعوته تمثل نموذجا واضحا يدلنا على قوة العلاقة بين التوابع ومتبوعاقا ، وهي علاقة تؤدي إلى تماسك النص القرآي وترابطه؛ لأن المقام - في كثير من الأحيان - يفرضها، والذي يدقق في استعمال النص القرآني فإنه يلاحظ أثر النعت في تماسك النص من خحلال تلك 
العلاقة القوية التي تربط بين النعت ومنعوته ، فإهما متلازمان في إطار

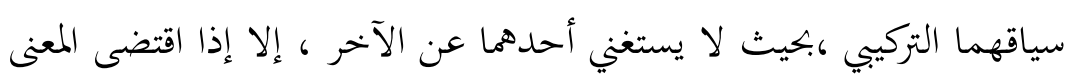
ذلك ، والشواهد القرآنية الدالة على ذلك كثيرة.

צ- توافرت التراكيب النعتية التي حققت التماسك النصي في سورة ( ق) بالربط بين المفردات، وبين الجمل ، والآيات وقد قدم النظام اللغوي وسائل كثيرة

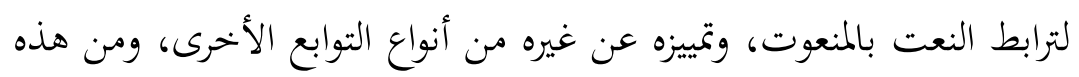
الوسائل المطابقة بين النعت والمنعوت في الإعراب والنوع والعدد والتبعية. - - يتضح أثر النعت في تحقيق التماسك النصي من خلال اشتراط الضمير الذي يربط بين الصفة والموصوف وأنه له دور كبير في إطالة بناء الجملة ويتضح هذا الدور بصورة أكثر في إطالة الجملة عند النعت بالجملة الاسمية والفعلية. 


\section{( Abstract)}

Through the study of research, it is clear to me the following:

1. The role of the epithet basis in cohesion text of the Koran as one of the most important disciples occupied ample space in the Quranic text in general, and in $\mathrm{Al}(\mathrm{s})$, in particular,

Surat has annexed (s) alone twenty-three complex Notaia among a number of verses of forty-five verse, the equivalent of one and fifty percent of the total mandates.

2. The role of the epithet in the text is generally to be very useful and comes to be, and that

grammarians put public assets determine the semantic role of the epithet.

3. that the most important role to play epithet in the cohesion of the Quranic text is fulfill the basic interest of the sentence with the participation of the news and others.

4 of the most important reasons that led to frequent epithet in the Qur'an in general, and in $\mathrm{Al}(\mathrm{s})$ in particular, the frequent epithet rise to the attention of the recipient, including thrown on him from across the indefinite article, then identifies and allocates this saying that the indefinite through qualities, have contributed this relationship in the cohesion of the 
verses of the Surah (s) and the formation of its meaning clearly.

5. The relationship between the adjective and Mnaute represents a clear example shows us the strength of the relationship between the disciples and Mtbuaadtha, a relationship which lead to the cohesion of the Quranic text and interdependent; because the place - often - imposed, which verified the use of the Quranic text he notes the role of the epithet in the cohesion of the text through the strong relationship between the adjective and Mnaute, they go hand in hand under Syakhma synthetic, so do not do without one another, but if necessary it meaning, and evidence of Quranic function on so many .

6. Alnotaih compositions that have achieved cohesion text in Surat available (s) linking vocabulary, between sentences, and verses have linguistic system offered many ways to thread the epithet Mounaot, and distinguish it from other types of other disciples, and the corresponding means between the adjective and Almnaot to express and type The number and dependency.

7. epithet clear role in achieving cohesion script by requiring conscience linking character and described and that he has a big role in prolonging the syntax and clear this role more in prolonging wholesale at wholesale epithet nominal and actual. 


\section{مقدمة:}

تأتي أهمية هذا البحث (أثر النعت في تماسك النص القرآني، سورة ق

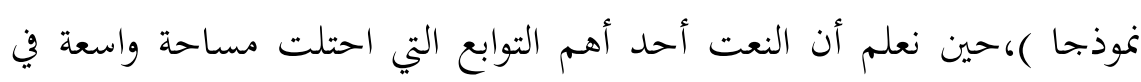

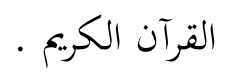

وقد اختار هذا البحث سورة (ق) نموذجا لما لمذه السورة من مكانة عظيمة ، فهي سورة مكية آياتا خمس وأربعون آية ، وعدد كلماتحا : ثلاثمائة وخمس وسبعون كلمة ، وعدد حروفها ألف وأربعمائة وأربع وسبعون حرفا .

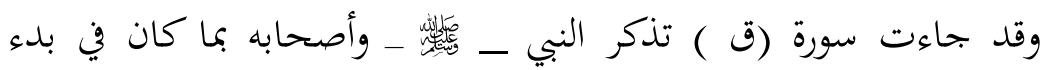

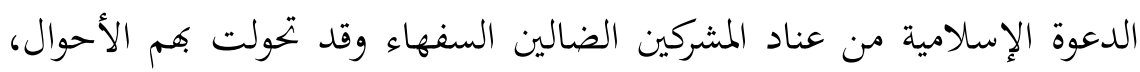
وأوشكوا أن يدخلوا في دين الله بعد أن كُسرت شوكتهم ، وبدأت غشاوة الضلال والسفه تنجلي عن أبصارهم، بما رأوا من إعزاز الله لدينه ،ونصرته لأوليائه،

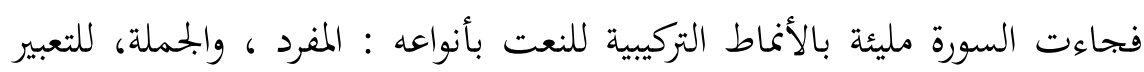
عن تلك الأحوال من خحلال التفاعل القائم بين دلالات الألفاظ ومعاني النحو. فقد ضمت سورة (ق)وحدها ثلاثة وعشرين نعتا من بين عدد آياتما البالغ خمسا وأربعين آية، أي ما يعادل واحداً وخمسين بالمائة من بحموع آياها. النعت لغة واصطلاحاً: يعد النعت أحد التوابع التي احتلت مساحة واسعة في القرآن الكريم بصفة عامة ، وفي سورة (ق) بصفة خحاصة . ولابد من التنبيه على أن مذهب جمهور النحاة أن العامل في النعت هو

$$
\text { العامل في متبوعه (i) }
$$


مصطلح النعت:

النعت في اللغة ما نعت به (ii)

وفي الاصطلاح: هو تخصيص الاسم بصفة هي له، أو لسبب يضاف

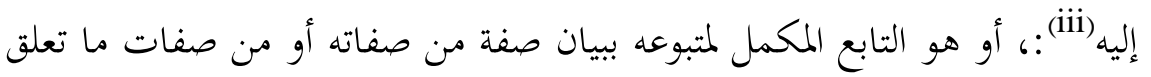
به،أي سببية (iv) ). وعلى هذا فالنعت على قسمين: إحداهما حقيقي، والأخر سبي. وقد اعتاد النحاة استعمال مصطلح النعت والصفة بمعنى واحد دون تفريق

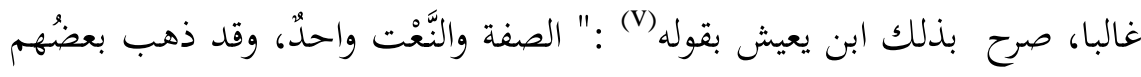

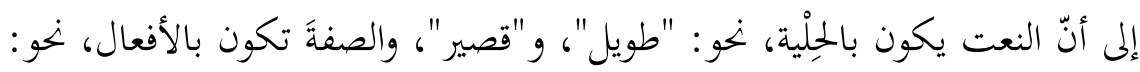

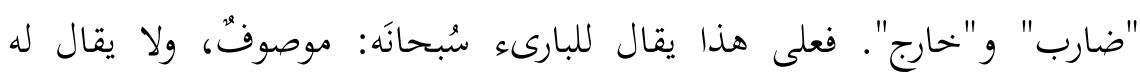
منعوتُ، وعلى الأوّل هو موصوفُ ومنعوتُّ.

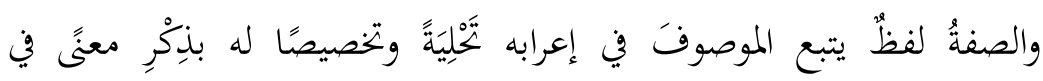

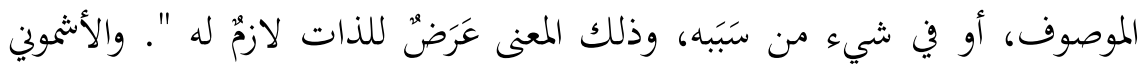

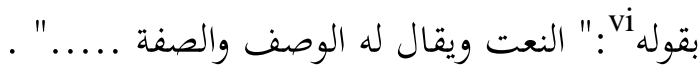
بيد أن هناك من النحاة من فرق بين المصطلحين في الاستعمال، نقل ذلك ولك

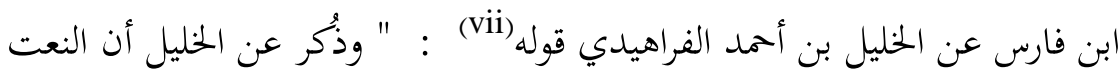

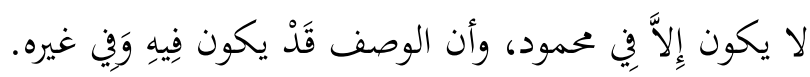

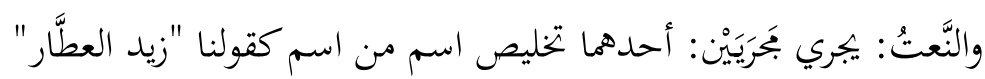

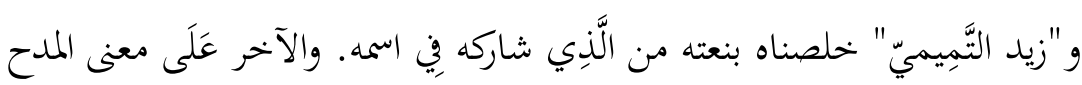

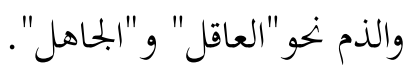
نخرج من هذا بنتيجة مفادها أن النعت والوصف مصطلح الحان كلا منهما يتحد

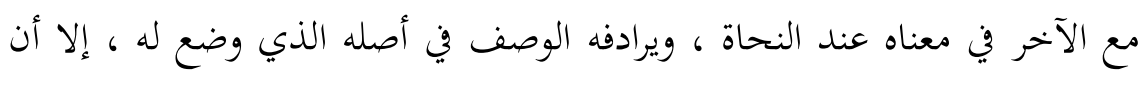

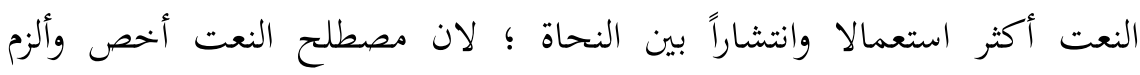

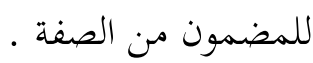




\section{معاني النعت وأثره الدلالي: - مأل}

من أغراض النعت تخصيص النكرة وإزالة الاشتراك العارض في المعرفة إذ يجب أن يُجعل للمعرفة - حال تعرى منها - مشاركة الاسم ليتميز به يقول ابن

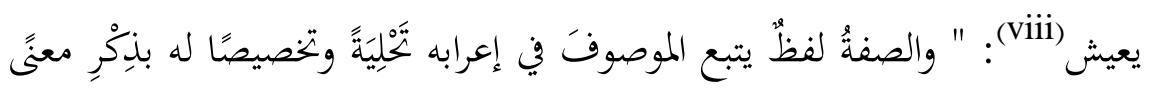
في الموصوف، أو في شيء من سَبَبه، وذلك المعنى عَرَضُ للذات لازٌْ له".

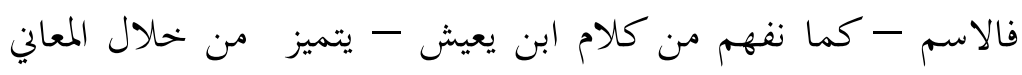

$$
\text { التي يضيفها النعت إلى المنعوت . }
$$

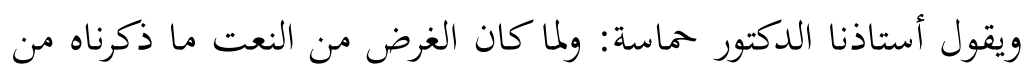

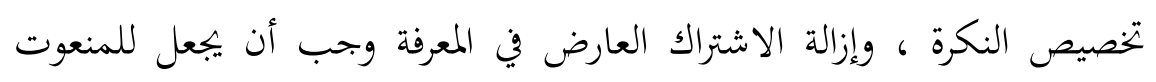
حال تعرى منها مشاركة في الاسم ؛ ليتميز به ، وذلك يكون بعدة وجوه إما بِِلْقَةٍ نحو : طويل ، وقصير ، وأبيض ، وأسود ، ونخوها من صفات الحلية ، وإما

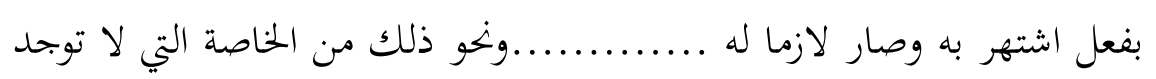
إلا في مشاركة "(ix)

وهي على وجوه منها: خِلْقُقَّةُ، كما في :طويل ، وقصير ،وأبيض ، وأسود ،ونحوها

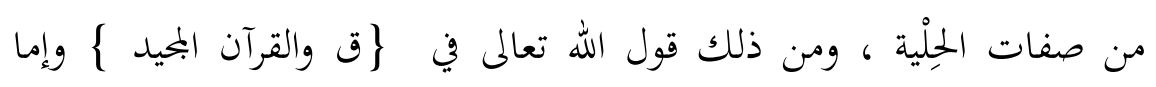

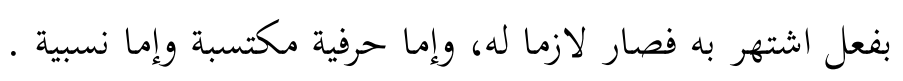

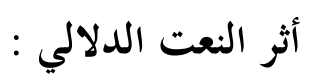

أثر النعت في النص يأتي عموما لتمام الفائدة والمراد بذلك ما يطلبه

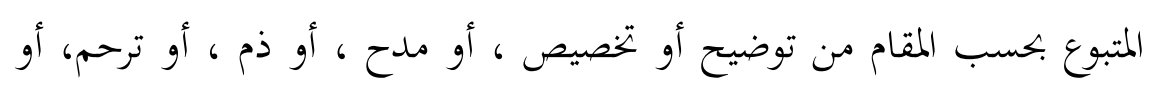
توكيد .

والدور الدلالي للنعت وظيفة سياقية ، بمعنى أن لكل تركيب خصوصيته

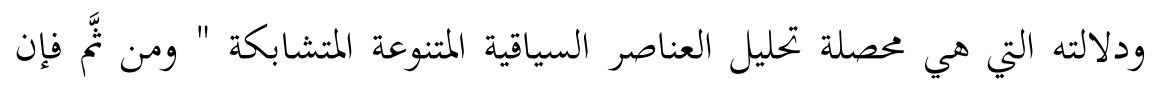


تحديد الوظيفة الدلالية هي أمر مرهون بالسياق بعناصره المتنوعة "(X)، ولابد أن ننوه أن ثمة " فرقا بين الصيغ النحوية ، والمعاني النحوية ، فالصيغ النحوية ثابتة

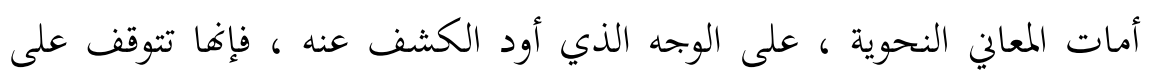

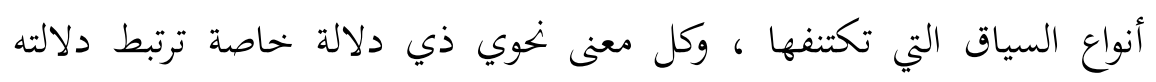

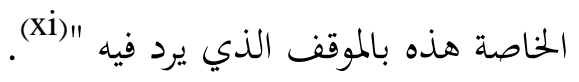

وقد وضع النحاة أصولا عامة تحدد الدور الدلالي للنعت من توضيح ، أو لو فيل تخصيص ، أو ملح ، أو ذم ، أو ترحم ، أو توكيد وقد تحققت هذه الأدوار الدلالية للنعت في معظم سور القرآن الكريم بصفة عامة ـوفي سورة ( ق ) بصفة خاصة . 
معنى التماسك النصي

إن موضوع التماسك النصي يتصل اتصالا مباشرا بالفكر حيث إن تماسك الرسالة اللغوية يرجع إلى تماسك المفاهيم التي تعبر عنها ، وتماسك المفاهيم يرتبط بتماسكها في ذهن قائلها ، حيث يرتب معانيه في رسالته حسب ترتيبها في نفسه (xii) بتماسل

ومن تََّّ فطبيعة التماسك في النص ما هو إلا " بحث في البنية الفكرية لصاحب النص وفي الصورة البنائية التي تمثل جزءا أساساً من أسلوبه (xiii). ولقد عد عبد القاهر الجرجاني تأليف البنية اللغوية للقرآن الكريم أهم أوجه

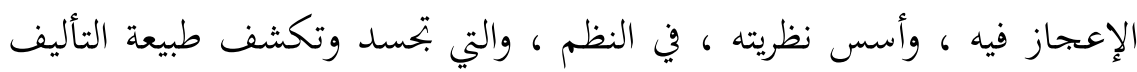
بين المفردات داخل المنظوم ؛ كما كشف في عبارة وجيزة عن العلاقة بين اللفظ والمعنى والفكر حين بين أن الناظم " يقتفي آثار المعاني ويرتبها على حسب ترتب

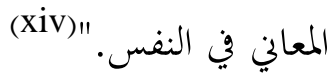

وقد عد ابن طباطبا التماسك ميزة يتميز بها ملفوظ عن آخر ، بقوله :"

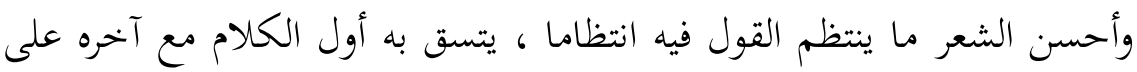
ما ينسقه قائله "XV).

فأفضل الشعر وفق كلامه هو ما يتسق أوله مع آخره ، وفق ما ينسقه قائله. هذا وقد كانت هناك إشارات عند معظم مفسري القرآن إلى التماسك وأهميته (xvi )

يقول ابن رشيق "العرب تنظر في تلاحم الكلام بعضه ببعض حتى عدوا من فضل

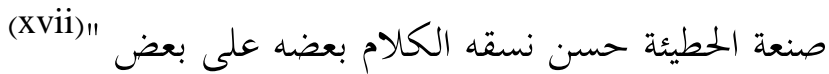
وقد أخذت دراسة التماسك حيزا كبيرا من اهتمام علماء النص ؛ وذلك بكس

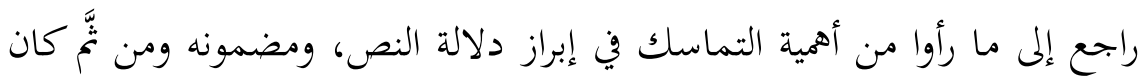


الاهتمام كبيرا بالتماسك، وأثره في إبراز دلالة النص، وعلاقته بنظم التفكير . وعلى هذا فالتماسك يعد بحثا في دلالة النص التي لا تتضح إلا من خلال تماسك مفرداته، وبناءً على ذلك نستطيع القول إن دراسة التماسك هي دراسة لدلالة النص، تكشف لنا عن تركيب النص كصرح دلالي (Xviii)، وعناصر هذا فئل التركيب، وأبرز الوسائل والعلاقات التي تربط بين عناصر النص، وأثرها في تشكيل نصيته.

ويقسم العلماء التماسك إلى قسمين: تماسك لفظي وهو ما يسمى عند بعض الباحثين بالسبك ،أو التضام، أو الاتساق، ويختص بالوسائل والأدوات التى تتحقق بها خاصية الاستمرارية في ظاهر النص ، وهذه الوسائل متعددة أهمها :الإحالة ، والربط بالأداة، والعلاقات النحوية، والحذف ، والتكرار ..........وهذا النوع من التماسك يهكمه النحو. أما القسم الثاني فهو التماسك الدلالي: وهو الحبك، أو التقارن، أو الانسجام فهو عند بعض الباحثين في غاية الأهمية(xix) ؛إذ إنه يكشف الونف الوحدة الدلالية للنص ،ويجسد استمرارية المفاهيم والعلاقات داخل النص. وينقسم التماسك الدلالي إلى تماسك دلالي طولي وتماسك دلالي كلي شامل (XX).. أما التماسك الدلالي الطولي فيبرز من خلال العلاقات بين معاني الجمل، وأما التماسك الدلالي الكلي الثامل فينطلق من البنية الدلالية الكبرى للنص، وموضوعه، وعنوانه. 


\section{أثر النعت في التماسك القرآني:}

أهم دور يقوم به النعت في تماسك النص القرآي هو تتميم الفائدة

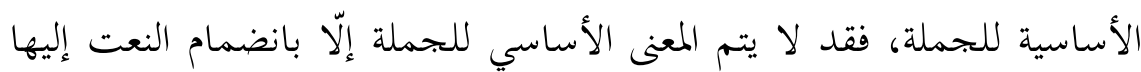
وهو غرض دلالي ففي قوله تعالى:

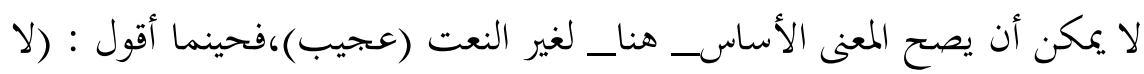
خير في شيء ضار).لافائدة في قولي (لا خير في شي؛) بل لا يصح أن يقال هنا

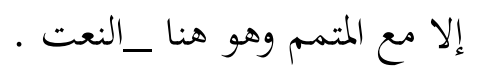

وقد أشار النحويون إلى هذا الدور الدلالي للنعت عند تعرضهم للنصوص

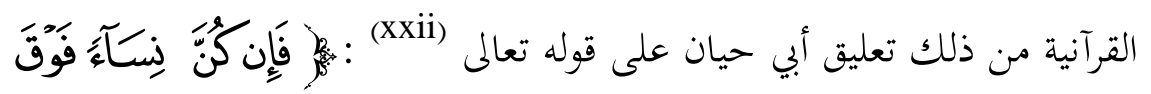

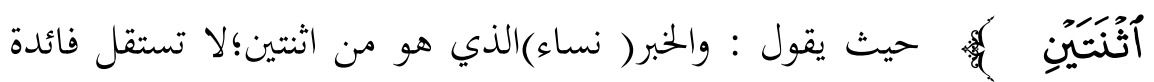
الإخبار بقوله (نساء ) وحده، وهي صفة للتأكيد ترفع ويراد بالجمع قبلها طريق البحاز؛إذ قد يطلق الجمع ويراد به التثنية وأجاز الزخشري أن يكون النساء خبرا ثانيا لكان ،وليس بشيء ؛ لأن الخبر لابد أن تستقل به فائدة الإسناد ولو سكت

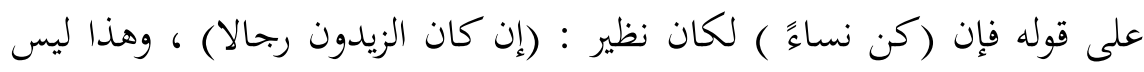
بكلام . قال بعض البصريين : التقدير وإن كان المتروكات نساء فوق اثنتين" (xxiii). ومفهوم كلام أبي حيان أن المعنى لا يتم دون نعت الخبر (نساء) في الآية السابقة من سورة النساء ،فالخبر _هنا _ـ بصفته هو (فوق اثنتين ) على حد إنى تعبيره ؛ إذ لا يمكن أن يستقيم المعنى بغير هذا النعت . فالنعت والمنعوت إذا عنصران متلازمان في سياق التركيب النحوي للجملة؛ وذلك لأن المنعوت يفتقر إلى نعته الذي يتمم معناه ؛ " فالنعت يتمم منعوته 
بدلالته على معنى في المنعوت ، أو في متعلقه ، يطلبه بحسب ما يقتضيه المقام من

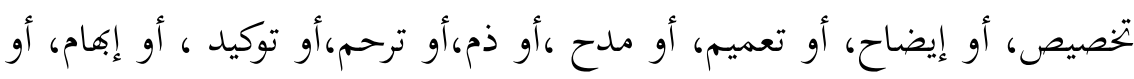

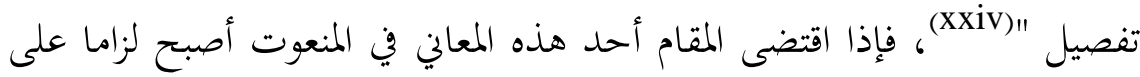
ذلك المنعوت أن يتضام إليه عنصر آخر وهو النعت ؛ لتحقيق ذلك المعنى ؛ وهذا يؤدي إلى قيام علاقة تلازمية بين النعت ومنعوته ، تبحلهما معا بمنزلة الشيء الواحد .

وقد عبر سيبويه عن تلك العلاقة القوية بين النعت والمنعوت بقوله :"فأما النعت الذي جرى على المنعوت، كقولك :مررت برجل ظريف قبلُ، فصار النعت

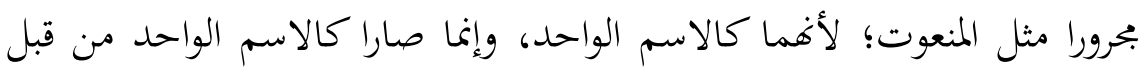
أنك لم ترد الواحد من الرجال الذين كل واحد منهم رجل، ولكنك أردت الواحد من الرجال الذين كل واحد منهم رجل ظريف، فهو نكرة، وإنما كان نكرة؛ لأنه

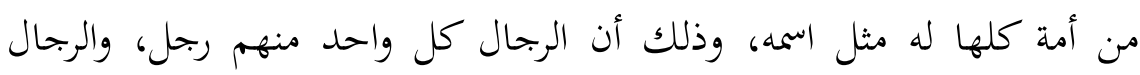
الظرفاء كل واحد منهم رجل ظريف، فاسمه يخلطه بأمته حتى لا يعرف منها" (XXV)

والملاحظ من كلام سيبويه هذا أنه يؤكد على العلاقة القوية بين النعت

$$
\text { والمنعوت لأها كالاسم الواحد وهي علاقة وثيقة . }
$$

كما وضح ابن يعيش ذلك أيضا في مفصله بقوله :"وإنما قلنا إهما كالشيء الواحد من قبل أن النعت يخرج المنعوت من نوع إلى نوع أخص منه،

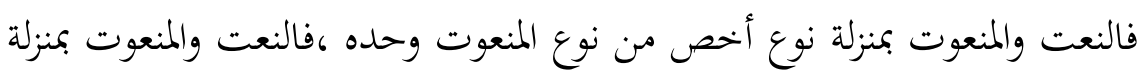

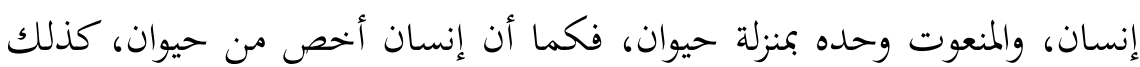
النعت والمنعوت أخص من النعت وحده" (xxvi). ولعل في تأكيد النحاة على ضرورة المطابقة-من حيث الإعراب والعدد 
والنوع والتعريف أو التنكير - بين النعت ومنعوته إشارة إلى تلك العلاقة القوية بحيث يصيران كالاسم الواحد فمن صور هذه المطابقة -مثلا- المطابقة في التعريف أو التنكير بينهما؛ حيث "لا توصف معرفة بنكرة ولا نكرة بمعرفة؛ لأن الصفة والموصوف شيء واحد ولا يصح أن يكون الشيء معرفا ومنكرا في آن واحد")(xxvii)

ولقد عقد المبرد بابا في مقتضبه يفهم من تسميته التأكيد على تلك العلاقة

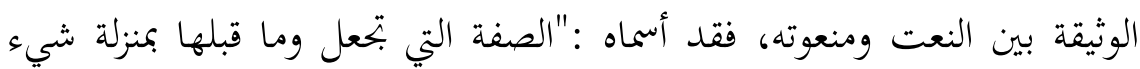

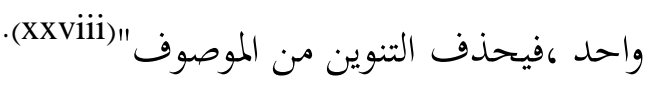

وقد أشار الأستاذ عباس حسن إلى أداء النعت بهذا الغرض ، ورأى أن الفائدة الأساسية للجملة قد لا تتم إلا بإجماع الخبر والنعت في بعض الأس الأحيان بقوله:((وقد يتمم النعت الفائدة الأساسية بالاشتراك مع الخبر مع أن الأصل في الخبر أن يتمّمم هذه الفائدة وحده لكنه في بعض الأحيان لا يتممها إلا بمساعدة

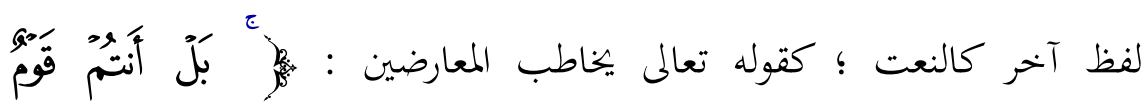

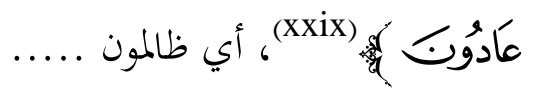

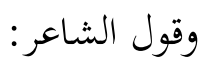

ونحن أُناس نحب الحديث ونكره ما يوجب المأثما

إذ لا تتحقق الفائدة بأن يُقال :نهن أناس ........لأن هذا معلوم بداهة

من القرائن العامة الموحيطة بالمتكلم "(XXX)

وإذا انتقلنا إلى سورة (ق) وجددنا أن النعت أدى هذا الدور في مواضع كثيرة

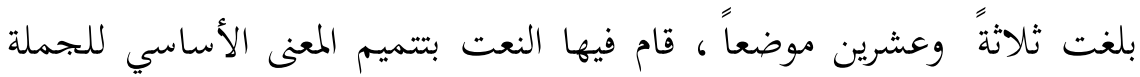
بمشاركة الخبر وغيره على النحو الآتي: 


\section{أولا : تتميم الفائدة الأساسية بمشاركة الخبر وما أشبهه:}

قد يكون الخبر قاصراً على تقديم فائدة الجملة الأساسية وذلك إذا كان أنسان معروفا من لفظ المبتدأ، فيكونان معا في حاجة إلى ما يتمّمم المعنى المقصود من الجملة ،وهنا يستعين النظام اللغوي بوسيلة أخرى كالنعت لإتمام المعنى المقصود من الجملة . nمل

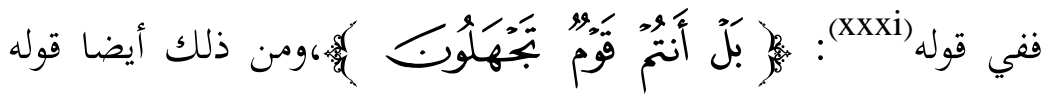

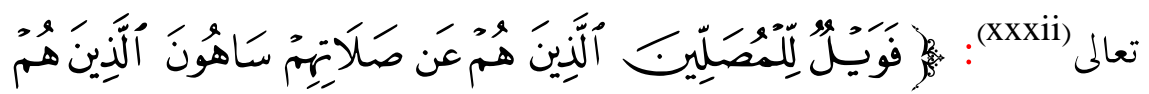

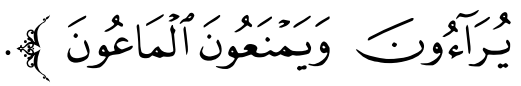
فلا يمكن أن يصح المعنى الأساسي هنا بغير النعت وما يتصل به كما ذكر xxxiii الأستاذ عباس حسن

ومما يدل -أيضا-على أن النعت هو أشد التوابع ارتباطا وأقواها تلازما مع متبوعه، أن النحاة يقدمونه على غيره من التوابع ، إذا اجتمع عدد منها ، فعندئذ

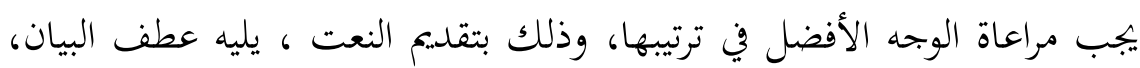
فالتوكيد، فالبدل ، فعطف النسق وذلك كا ورد في هذا النظم :

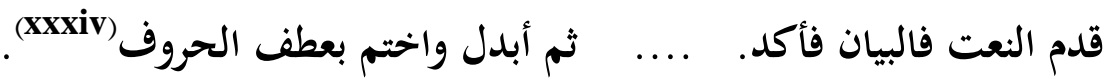
ويفسر لنا السيوطي الأفضلية في الترتيب بين التوابع بقوله : " وإذا اجتمعت - يقصد التوابع - رتبت كذلك ،بأن يقدم النعت ؛ لأنه كجزء من متبوعه ، ثم

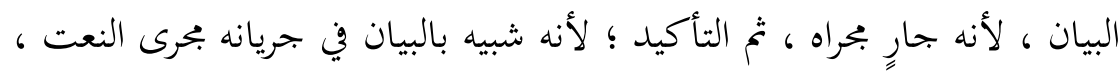
تم البدل ؛ لأنه كلا تابع ؛ لكونه مستقلا ، تمخ النسق ، لأنه تابع بواسطة" (XXXV).

ومن هنا فالعلاقة بين النعت ومنعوته تمثل نموذجا واضحا يدلنا على قوة العلاقة 
بين التوابع ومتبوعاها ، وهي علاقة تؤدي إلى تماسك النص القرآني وترابطه؛ لأن

$$
\text { المقام - في كثير من الأحيان - يفرضها. }
$$

والذي يدقق في استعمال النص القرآني فإنه يلاحظ أثر النعت في تماسك النص من خلال تلك العلاقة القوية التي تربط بين النعت ومنعوته ، فإهما متلازمان في إطار سياقهما التركيبي ،بحيث لا يستغني أحدهما عن الآخر ، إلا إذا اقتضى المعنى ذلك ، ومن الشواهد القرآنية الدالة على ذلك بهيك قوله تعالى (xxxvi) :

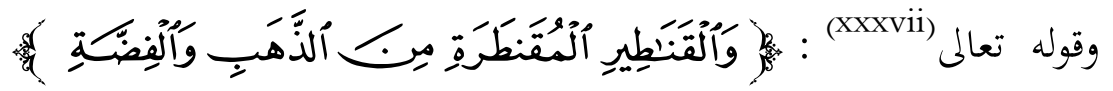

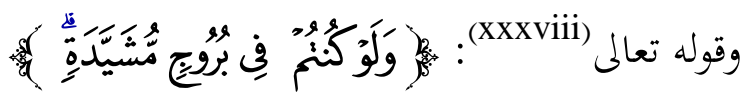

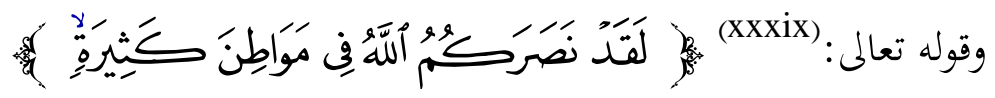

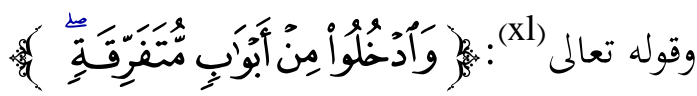

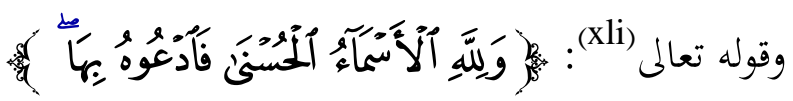

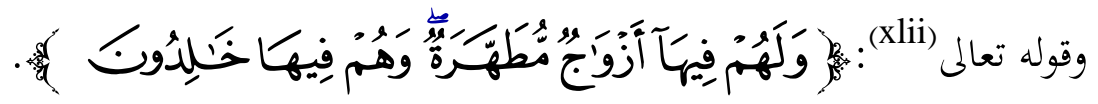
في هذه الآيات الكريمة تحقق التماسك النصي من خلال التماسك المعنوي بين النعت ومنعوته ، فالنعوت (كثيرة، المقنطرة ، مشيدة ، كثيرة ، الحسنى ، أزواج) فهي على الترتيب نعوت لـ (أضعافا ، القناطير،بروج ، مواطن، الأسماء، مطهرة).

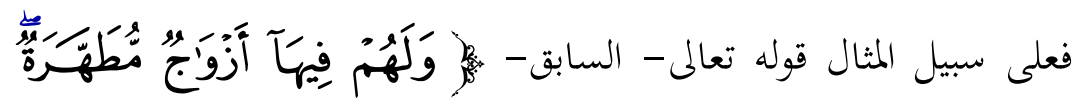

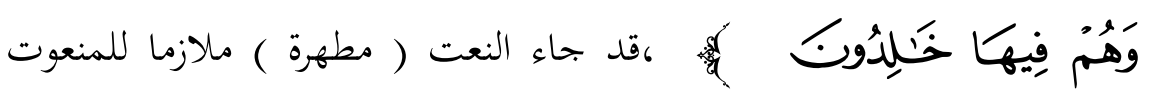
(أزواج) ؛ ليكمل دلالته ، ويتمم معناه ، وهذا النعت يسميه النحاة نعتا حقيقيا،

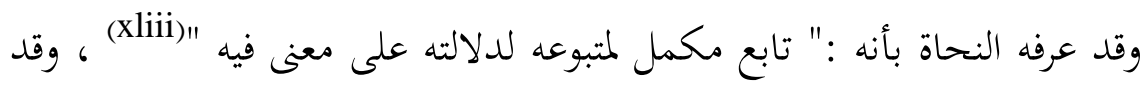


حقق النعت هنا تماسكا نصيا من خلال التماسك المعنوي بينه وبين منعوته

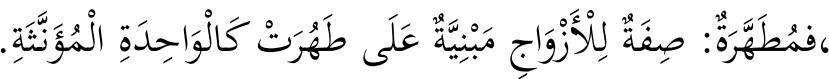

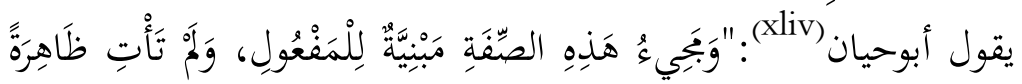

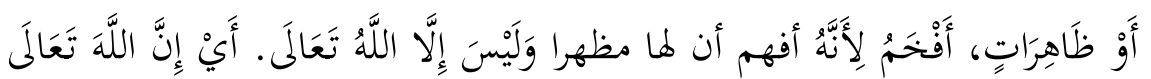

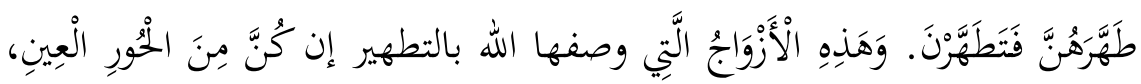

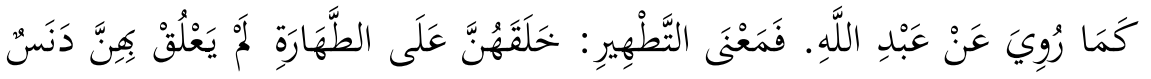

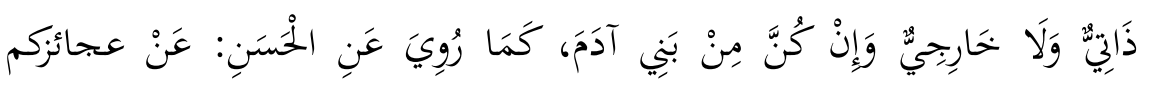

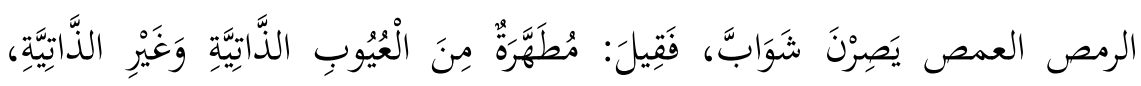

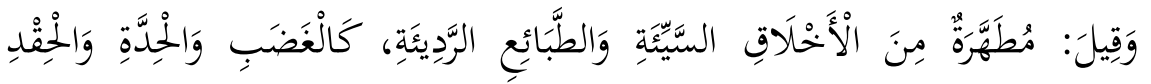

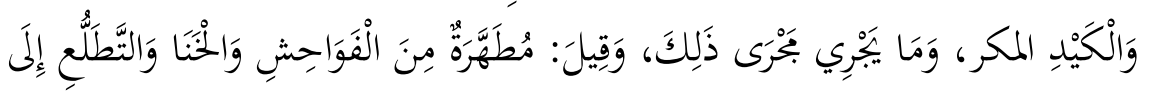

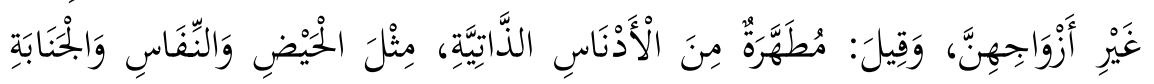

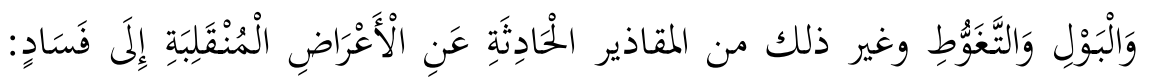

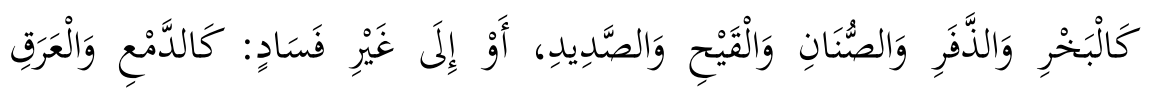
وَالْبُصَاقِ وَالنُخَحَامَة.

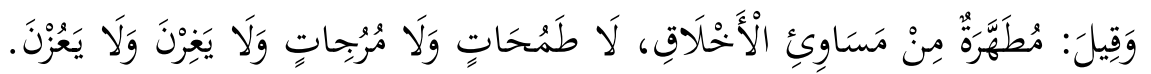

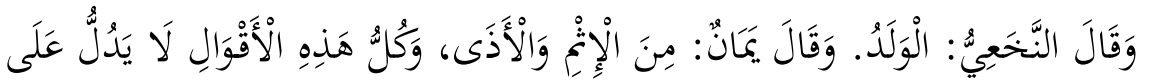

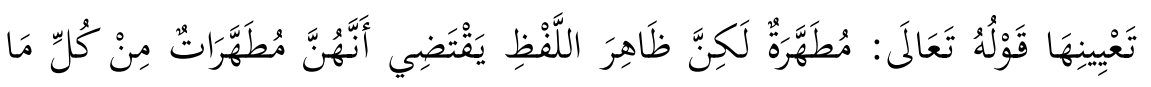

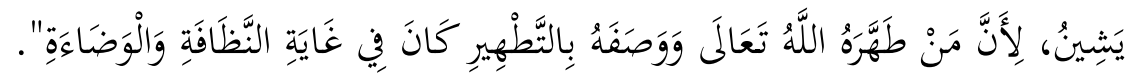

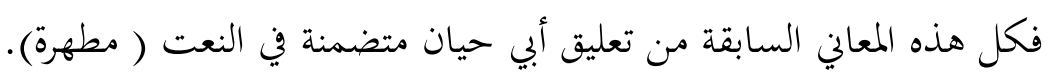
ومن ورود ذلك في سورة ( ق ) قوله تعالى (Xlv):

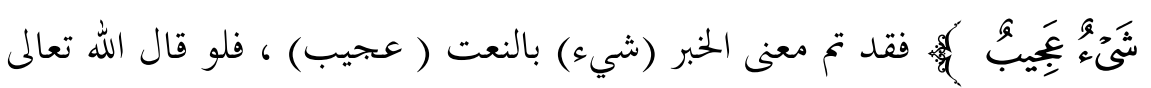


" فقال الكافرون هذا شيء" وسكت لما أفاد شيئاً.

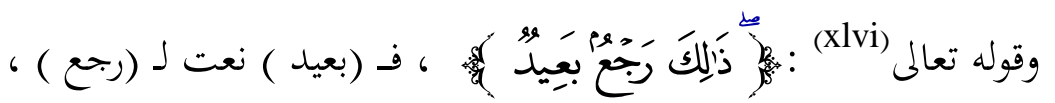

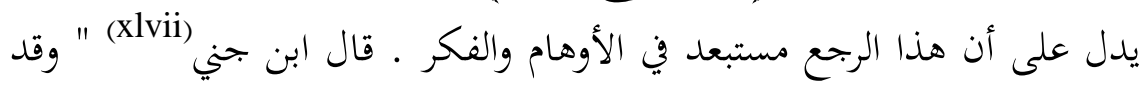

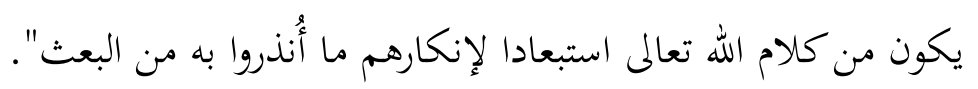

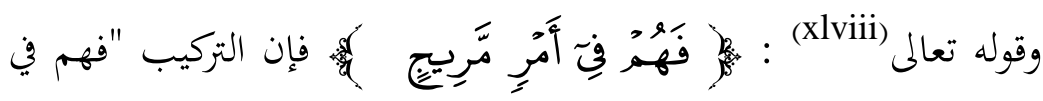
أمر" ، لا يؤدي المعنى المقصود بدون النعت " مريج " فلا تتحقق الفائدة الأساسية للجملة دون انضمام النعت إلى الجملة ، وقد أفاد النعت في هذا السياق الاضطراب والاختلاط في كلام الكافرين ، فقد اختلط الامر عليهم والتبس :مرة ساحر ، ومرة شاعر ، ومرة كاهن ، ولولا النعت لما تحققت هذه وله الفائدة التي أراد الله أن يظهر عليها أمر الكافرين من اللبس واختلاط الأمر عليهم من القلق باعتبار انتقال أفكارهم فيما جاء به المنذر إلى عدم قبوهم أول إنذاره

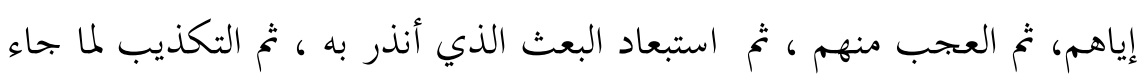
به.

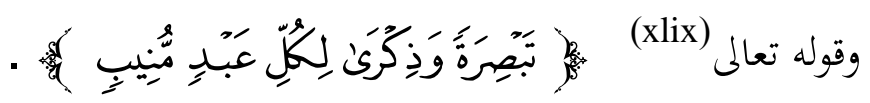

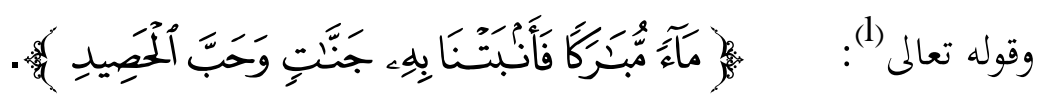

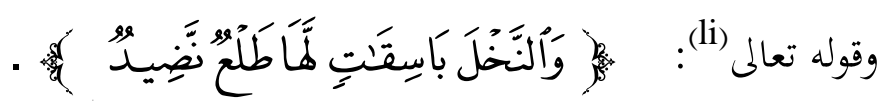

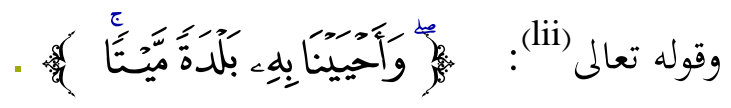

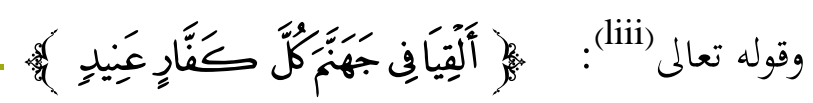

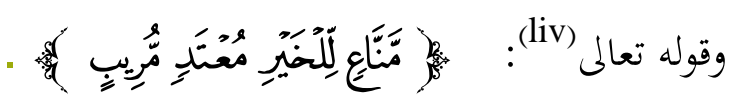

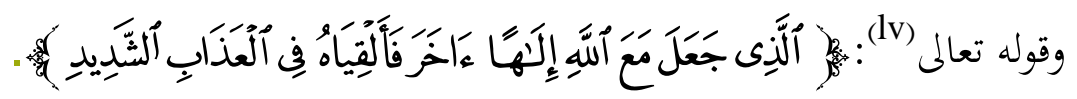




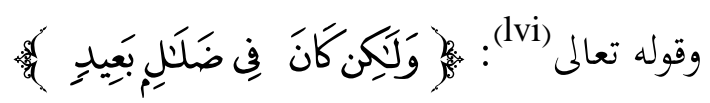

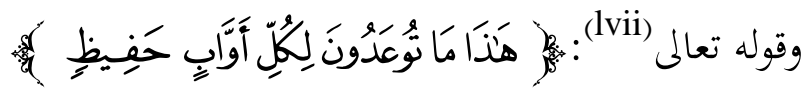

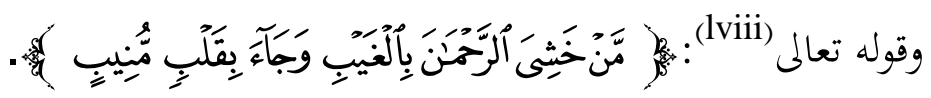

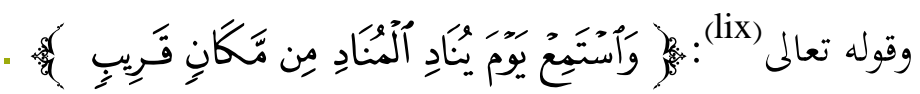

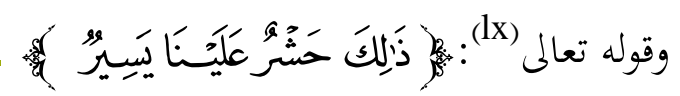

وهكذا تدل الشواهد القرآنية المذكورة على أن ثمة علاقة تلازمية وثيقة

تربط بين النعت والمنعوت ؛ وذلك لأن النعت متمم لمتبوعه ؛لدلالته على معنى فيه أو فيما يتعلق به ، ويؤكد تلك العلاقة ما اشترطه النحاة من ضوابط التطابق بينهما من حيث النوع: ( تذكيرا وتأنيثا) ،والعدد:

( إفرادا وتثنية وبمعا )،والتعريف والتنكير ،والإعراب: ( رفعا ونصبا وجرا ).

فلا ريب أن تلك المطابقة بين النعت والمنعوت تقوي الصلة بينهما ، حيث

إن تلك المطابقة هي نفسها قرينة على ما بينهما من ارتباط وتماسك في المعنى، وتكون قرينة لفظية تتضافر مع التلازم والتماسك بينهما .

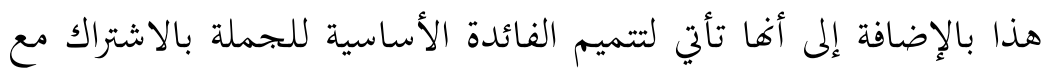

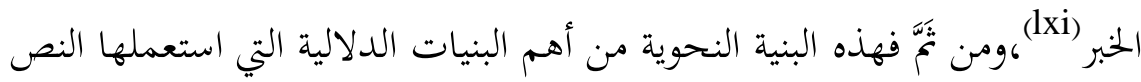
القرآي في سورة ( ق ) للتعبير عن المعنى بدقة ، فتحققُ وضوحَ المرادِ ، وتسهم في بحاح عملية التواصل اللغوي ، وتحقق هذه العلاقة النحوية التماسك النصي في

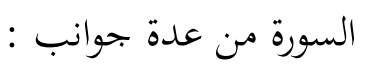
1 - " التعدد بنية الوصف النحوية ومعاقبة الجملة للمفرد ، وتداخلها ، فتسهم

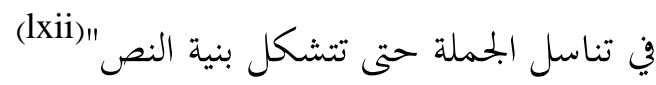

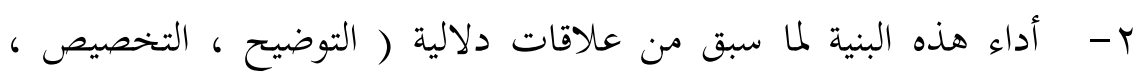


والتأكيد) ، وهي علاقات هامة تحقق التماسك الدلالي.

r- - يمثل النعت نوعا من الرجوع إلى الوراء " فهي تعيد المتلقي إلى بنية الموصوف ولاسيما إذا تعددت الصفات ، فطالت المسافة النصية بين النعت والمنعوت، كما تنقل المتلقي إلى الأمام من الصفة إلى الموصوف ، وخاصة إذا كان الموصوف نكرة، حيث إنه بتنكيره وما يتصل بالنكرة من عموم ، يحدث شيئا من الإبهام يدفع المتلقي إلى الانتقال سريعا إلى العنصر

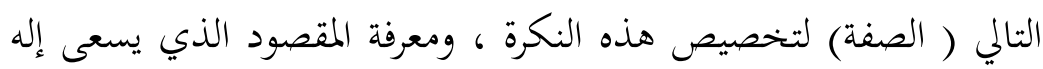
المتلقي بقراءته، ويهدف إليه المتكلم بكلامه (lxiii).

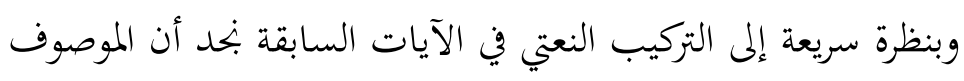

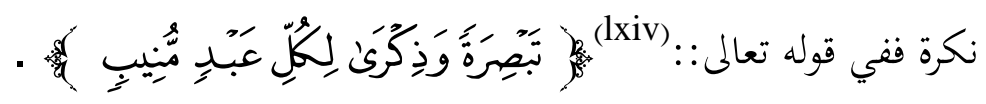

جاء الموصوف(عَبِدٍ ) نكرة فأحدث شيئا من الإبهام شيئا الإهمام مما يدفع المتلقي إلى الانتقال سريعا إلى العنصر التالي الصفة(مَّنِيِبِ ) لتخصيص هذه النكرة ، ومعرفة المقصود الذي يسعى إله المتلقي بقراءته، ويهدف إليه المتكلم بكلامه وقس على ذلك باقي التراكيب السابقة. ولعل ذلك يعد أحد أهم الأسباب التي أدت إلى كثرة النعت في القرآن الكريم بصفة عامة ، وفي سورة ( ق ) بصفة خاصة، فإن كثرة النعت تؤدي إلى إثارة انتباه المتلقي بما يلقى عليه من عموم النكرة ، ثم يحدد ويخصص هذا التنكير من خلال الصفات.

هذا ، وقد أسهمت هذه العلاقة في تماسك آيات سورة ا( ق ) وتشكيل دلالتها بصورة واضحة ولعل نظرة سريعة لما ذكرته من الآيات السابقة 


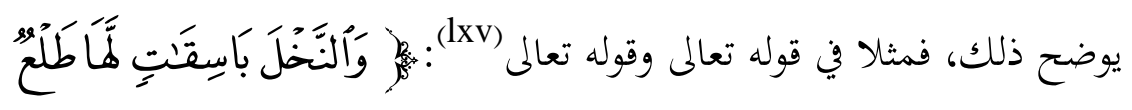

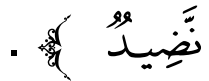

بحد أن النعت يطابق منعوته في الإعراب ( رفعا) ، وفي النوع ( تذكيراً) ، وفي العدد (إفرادا)، وفي التنكير.

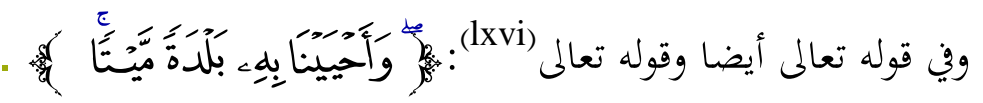
بند أن النعت يطابق منعوته في الإعراب ( نصبا) ، وفي النوع ( تأنيثا) ، وفي العدد (إفرادا)، وفي التنكير -

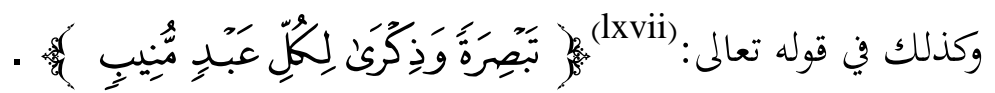

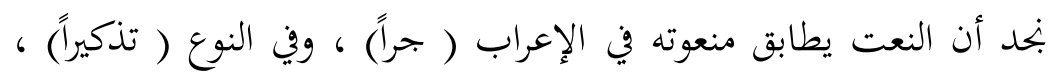
وين العدد (جمعا)، وفي التنكير. مما سبق يتضح لنا توافر التراكيب النعتية التي حققت التماسك النصي في السورة بالربط بين المفردات ، وبين الجمل ، والآيات ، ويمكن بيان أثرها من خلال تحليل بعض الآيات. وعلى هذا فالنعت من أهم الوسائل اللغوية التي تحقق التماسك في النص بِعدّه واحدا من التوابع "التي تمثل مرحلة من المراحل النصية التي تستعرض وسائل التماسك النصي وأثرها في التحليل النصي" "lxviii). 
ثانيا : المطابقة ببن النعت والمنعوت:

يقدم النظام اللغوي وسائل كثيرة لترابط النعت بالمنعوت وتمييزه عن غيره

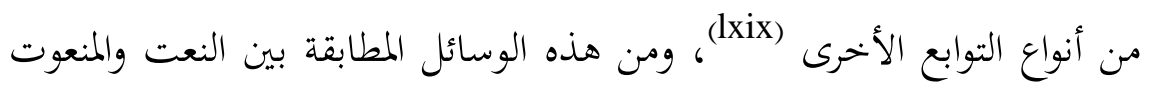
في الإعراب والنوع والعدد والتبعية وقد قرر الزخشري في مفصله هذا الأصل بين الصفة والموصوف بل قاس عليه أنواع التطابق الأخرى بين النعت ومنعوته، يقول:"وكما كانت الصفه وفق الموصوف في إعرابه، فهي وفقه في الإفراد والجع، والتعريف والتنكير (lxx).

وشرح هذا القول ابن يعيش في قوله: "الصفة تابعة للموصوف في أحواله، وجملتها عشرة أشياء: رفعه ونصبه، وخفضه، إفراده وتثنيته وجمعه، وتنكيره وتعريفه، وتذكيره وتأنيثه، إن كان الاسم الأول المصفوف مرفوعًا فنعته مرفوع، وإن كان منصوبًا فنعته منصوب، وإن كان مخفوضًا فنعته مخفوض، وكذلك سائر

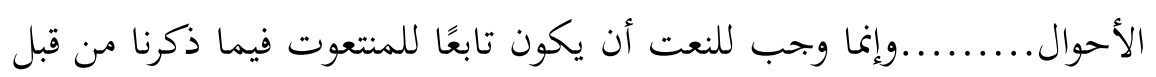
أن النعت والمنعوت كالشيء الواحد، فصار ما يلحق الاسم الاسم يلحقه وله

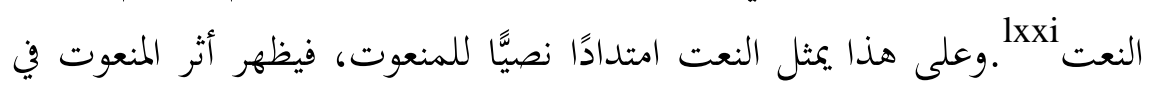

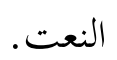

يدل هذا كله على قوة التماسك بين النعت والمنعوت فهما كالاسم الواحد كما أشار سيبويه وإنما يبيء النعت لتتميم النعوت وتكميلها ؛ذلك أنه دالّ على معنى في المنعوت أو في متعلَّقه على حد تعبير ابن مالك في ألفيته: النعت تابع مُتم ما سبق..................

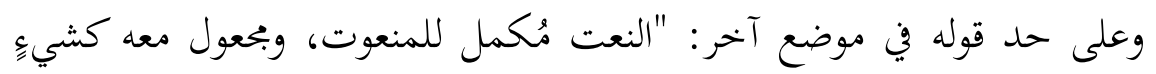
واحد") وعلي (1xxii) وحينما يكون النعت جملة، فقد اشترط النحويون وجود ضمير في هذه الجملة 
يربطها بالمنعوت، "وهذا الضمير هو وسيلة أخرى من وسائل التماسك النصي (lxxiii).

يقول ابن عُقيل في شرحه على الألفيَّة تعليقًا على قول ابن مالك:

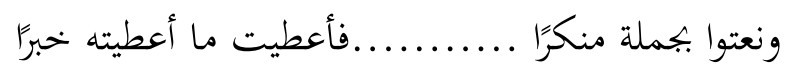

(وأشار بقوله :"فأعطيت ما أعطيته خبرًا"إلا أنه لابد للجملة الواقعة صفة من ضمير يربطها بالموصوف، وقد يحذف للدلالة عليه (lxxiv).

وفي نص دال يذكر الرضي علة اشتراط الضمير في الجملة الواقعة نعتا للنكرة فيقول تعليقا على قول ابن الحاجب : " وتوصف النكرة بالجملة الخبرية ، ويلزم الضمير". قوله : " ويلزم الضمير " ، إنما اشترط الضمير في الصفة والصلة ليصل به ربط بين الموصوف وصفته ،والموصول وصلته ، فيحصل بذلك ربط بين الموصوف وصفته والموصول وصلته ، فيحصل بذلك الربط اتصاف الموصوف والموصول بمضمونه

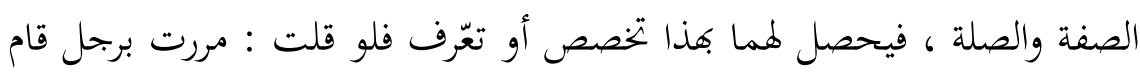

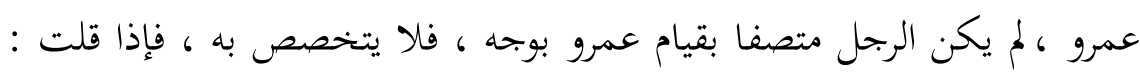
قام عمرو في داره ، صار الرجل متصفا بقيام

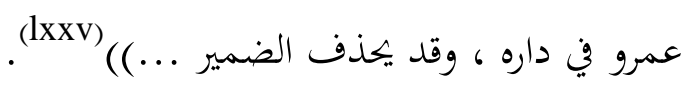

هذا النص يبزر أثر النعت في تحقيق التماسك النصي من خلال اشتراط الضمير

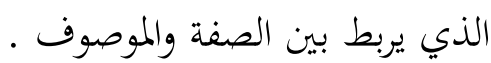
فلا شك أن المطابقة بين النعت ومنعوته تقوي الصلة بينهما ، حيث تكون هي نفسها قرينة على ما بينهما من ارتباط في المعنى ، وتكون لفظية تتضافر للترابط بينهما وقد اتضحت صور هذه المطابقة من خلال تلك الشواهد القرآنية السابقة

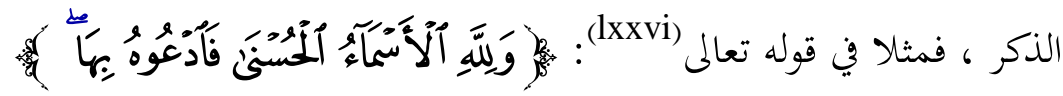


بند أن النعت يطابق منعوته في الإعراب ( رفعا ) ، وفي النوع ( تأنيثا) ، ووين (العدد) جمعا ، وفي التعريف .

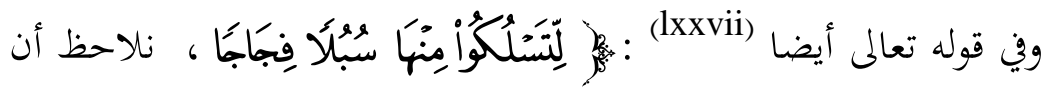
النعت طابق منعوته في الإعراب ( نصبا ) ، وفي النوع ( تأنيثا ) ، وفي العدد (جمعا ) ) و وفي التذكير.

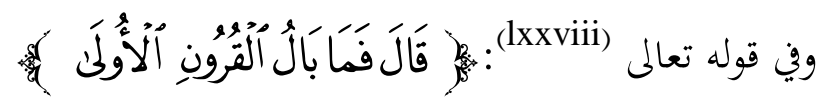
بنحد أن النعت طابق منعوته في الإعراب ( جرا ) ، وفي النوع ( تأنيثا ) ، وفي العدد (إفرادا)،حيث يعامل جمع التكسير معاملة المفرد المؤنث ، ويطابقه في التعريف كذلك و ل ولقد توفَّت التراكيب النعتية محققة التماسك النصي في سورة (ق) ، وقد

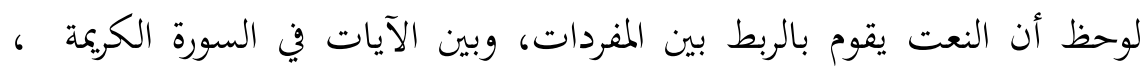

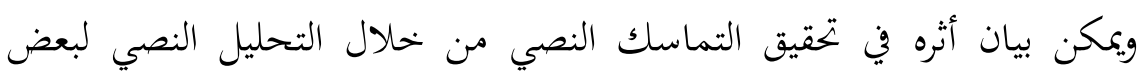
آيات سورة (ق) .

باديء ذي بدء نقرر أنه من خلال تتبعنا للنعت في سورة (ق) وجدنا أن

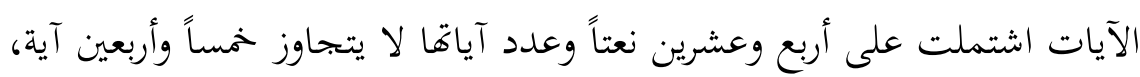
أي أن عدد ما ورد في السورة من آيات مشتملة على نعوت يكاد يتجاوز نصف لهف لهات آيات السورة كاملة ، هذه النعوت أسهمت في تحقيق التماسك النصي، والعلاقة الأساس التي تحكم هذا التماسك هي علاقة الإسناد بين المنعوت والنعت ففي قوله تعالى:\} فهم في أمر مريج \{ُ، فقد جاء الوصف بالصفة المشبهة

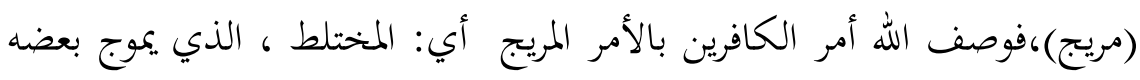
في بعض، والمر المريج الذي فيه هؤلاء الكافرون ،هو اضطراب مقولاتمم في الرسول 
الكريم، ويف القرآن البميد شأفم في هذا شأن من يركب متاهات الطرق وطوامسها، فلا يدري في أي ابتحاه يتجه ....فإنه يتجه تارةً يمينًا وتارةً شمالًا، ومرةً

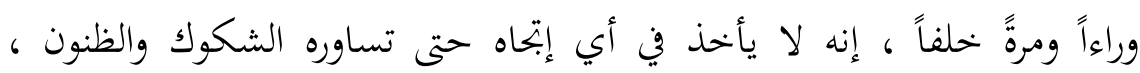
فيعدل عنه إلى غيره ، الذي يحسب أنه الطريق القاصد ، ثم لا يلبث أن يتهم نفسه في ما حسب فيعدل وهكذا ..... هذا شأن الإنسان وحده مع نفسه وقد عبرت الصفة المشبهة ، مريج على وزن فعيل من الثلاثي (مرج) ابلغ تعبيرٍ عن مدى هذا الاضطراب والاختلاط الذي فيه هؤلاء من أمرهم ومن باب الإسناد

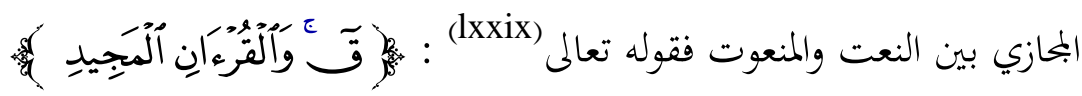
وصف الله تعالى (القرآن ) بذلك؛ لأنه كلامه المجيد ، فهو وصف يصفه قائله فالإسناد بحازي. ثالثا :إطالة بناء الجملة بالنعت: كما أشرنا سابقا فإن النعت يعد بمثابة تقييد للمطلق ( المنعوت ) ، أو بأو أو تحديده ، أو تخصيصه ، أو توضيحه ومن خلال تلك الدلالات التي لايستغنى

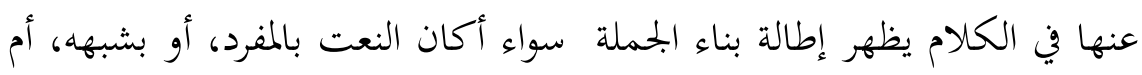
كان بالجملة، أو شبهها ، وعند حذف ما تطول به الجملة يكون في الكلام ما يدل عليه بعد حذفه " فالنعت والمنعوت كالشيء الواحد ، فالمنعوت لا يتضح

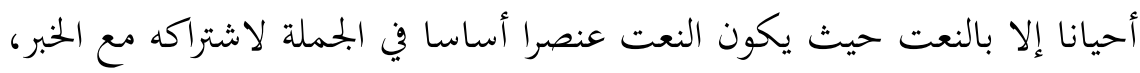

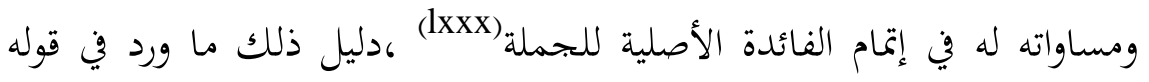

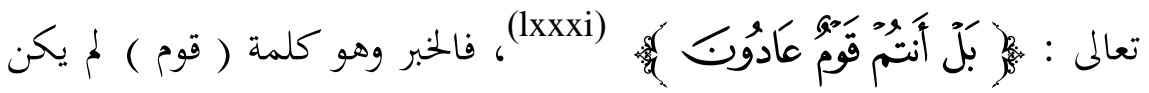
كافيا في إتمام المعنى منفردا عن الصفة ، بل كان في حاجة إلى هذه الصفة لإتمام المعنى والفائدة .... فيكون النعت هو العنصر الأساس في الجملة ، وبه يكتمل 
المعنى وتتم الفائدة الأصلية للجملة ...... ، وبذلك يكون النعت عمدة وليس فضلة"(lxxxii)

فالتركيب - كما نفهم من الآية السابقة - لم يزد عن عن المبتدأ (قوم) ، والخبر (عادون ) فـ " تركيبه في الجملة أحدث من عدمه ؛ حيث كان التركيب

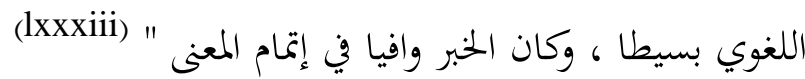
يفهم من ذلك أن النعتت لا يكون فضلة وأنه يطيل بناء الجملة ، ويشترك وكئ

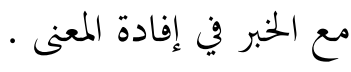

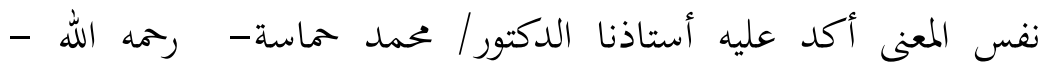

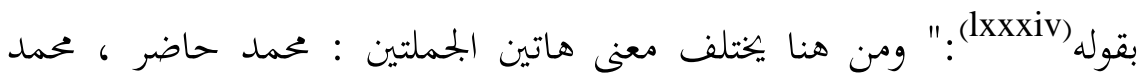
العاقل حاضر ؛ لأن التابع والمتبوع معا يكونان ما يمكن أن يسمى مركبا اسميا يكون المتبوع فيه هو رأس هذا المركب الاسمي الذي يترابط بعلاقاته الخاصة به في

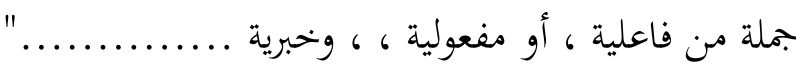

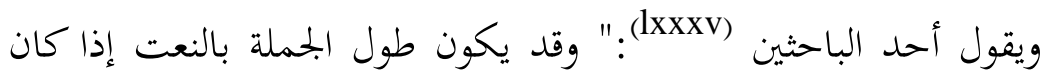
الثاني يكمل متبوعه بدلالة على معنى فيه ...." . . . .

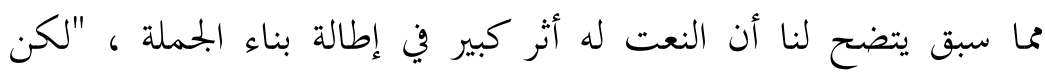
بعض النعوت يكون أثرها في إطالة بناء الجملة أوضح وأظهر فمثلا إذا كان النعت ب (ذو) بمعنى صاحب؛ فإها تحتاج مضاف إليه ، وكذلك إذا كان النعت بالاسم الموصول ؛ فإنه يحتاج إلى جملة الصلة بعده كي يتعرف بها ، وهذه الجملة قد بد

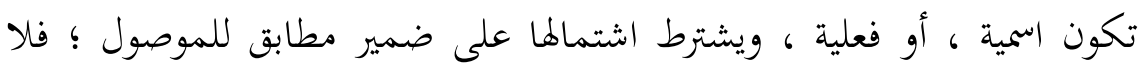

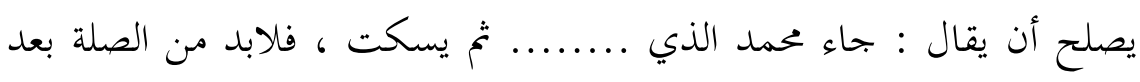
الموصول ................. ويتضح أثر النعت بصورة أكثر وضوحا في إطالة الجملة عند النعت بالجملة الاسمية والفعلية ، ويتضح طول الجملة أكثر عند النعت 
بالجملة الشرطية التي تستدعي : أداة شرط ، وفعل شرط ، وجواب شرط فتطول الجملة بهذا التركيب الشرطي الواقع نعتا "(lxxxvi).

كل تلك الشروط التي اشترطها النحاة في النعت تطيل بناء الجملة

الأصلي، فلا ينظر إلى النعت على أنه كلمة مفردة ، بل ينظر إليه على أنه تركيب يعطي فائدة ومعنى أيا كان طول هذا النعت ، وأيا كان تركيبه ونوعه.

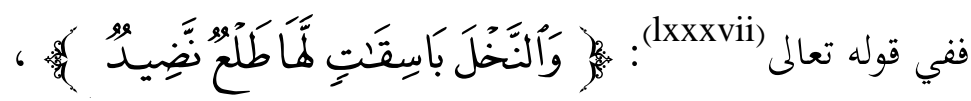

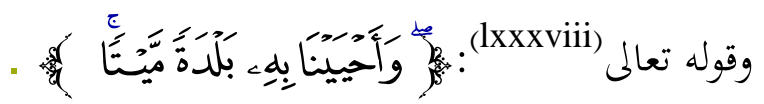

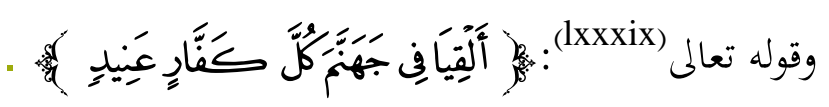

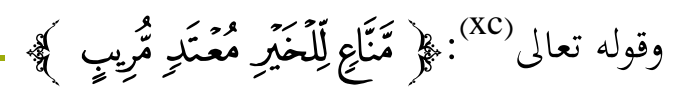

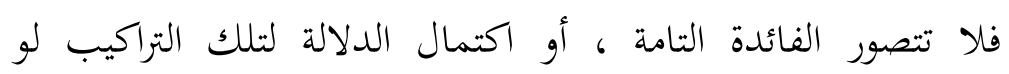

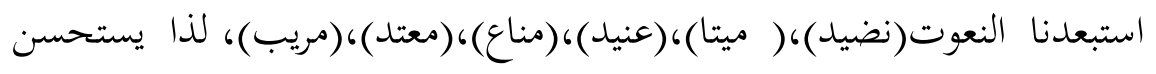
اعتبار مثل هذه النعوت مكملات مفيدة ، ولا نعدها من الفضلات. 


\section{النعت بالجملة الاسمية :}

ينعت بالجملة على أن يكون منعوتها نكرة محضة (xci) يقول الرضي (xcii)."

فإن قيل: فإذا لم تكن الجملة لا معرفة ولا نكرة، فلم جاز نعت النكرة بها دون

المعرفة؟

قلت: لمناسبتها للنكرة، من حيث يصح تأويلها بالنكرة، كما تقول في، قام

رجل ذهب أبوه، أو: أبوه ذاهب: قام رجل ذاهب أبوه، وكذا تقول في، مررت

برجل أبوه زيد: إنه بمعنى: كائن أبوه زيدا، وكل جملة يصح وقوع المفرد مقامها ،

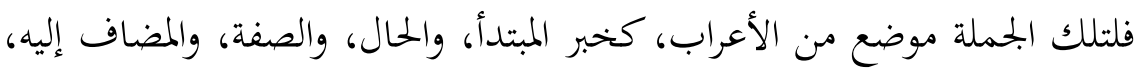
ولا نقول إن الأصل في هذه المواضع هو المفرد، كما يقول بعضهم، وإن الجملة إنما

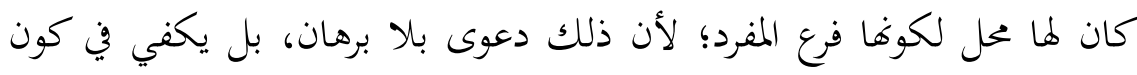
الجملة ذات محل: وقوعها موقعا يصح وقوع المفرد هناك ، كما في المواضع المذكورة، وقال بعضهم: الجملة نكرة، لأفها حكم، والأحكام نكرات، إشارة إلى ولى أن الحكم بشئ على شئ، يجب أن يكون بجهولا عند المخاطب إذ لو كان معلوما، لوقع الكلام لغوا، نحو: السماء فوقنا، والأرض تحتنا، وليس بشئ؛ لأن معنى التنكير، ليس كون الشئ بحهولا ، بل معناه في اصطلاحهم: ما ذكرت الآن، أعني كون الذات غير مشار بها إلى خارج إشارة وضعية، ولو سلمنا أيضا، أن

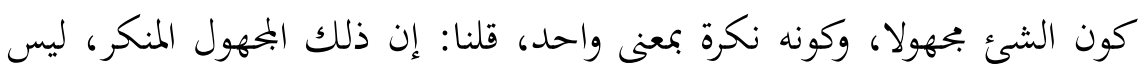

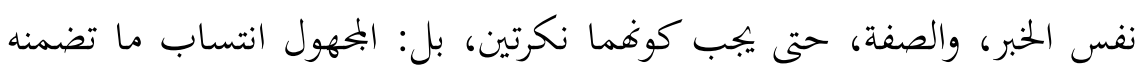
الخبر والصفة مضافا إلى المحكوم عليه، كعلم زيد، في جاءلي زيد العالمها: و(زيد

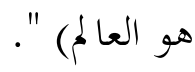

فيتحقق بوصفها للنكرة شرط التطابق بين النعت والمنعوت في التعريف

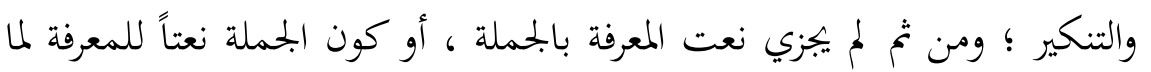


يترتب عليه من فقدان ذلك الشرط .

ولكن اللغة لم تقف عند ذلك الحد ؛ فأشار النحاة إلى أن اسم الموصول

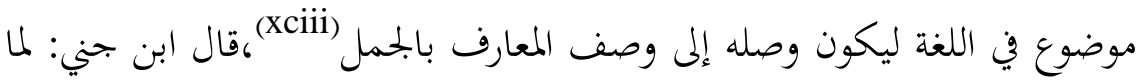

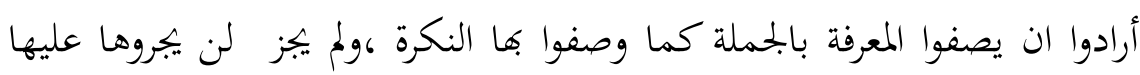

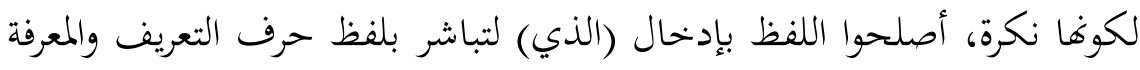

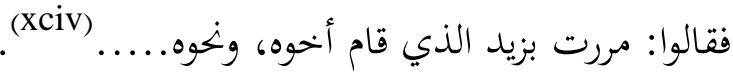

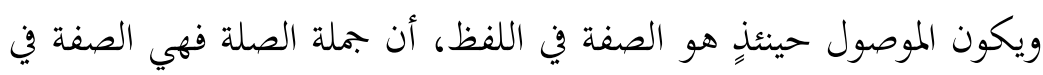

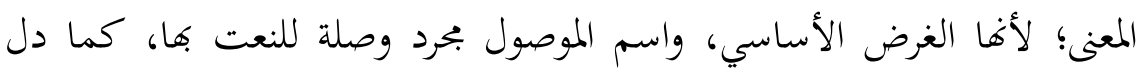

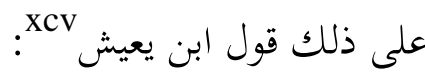

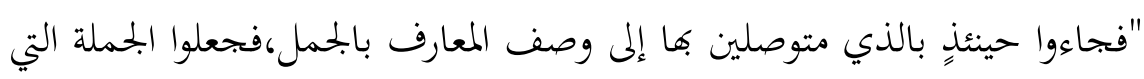

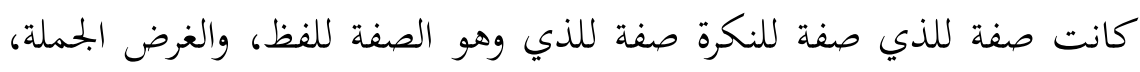

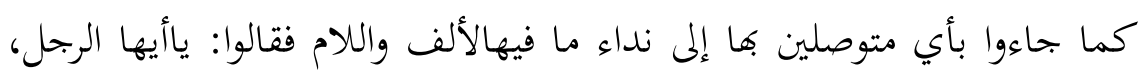
والمقصود نداء الرجل، وأي وصلة....... ".

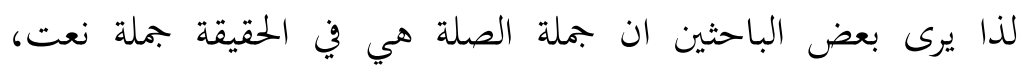

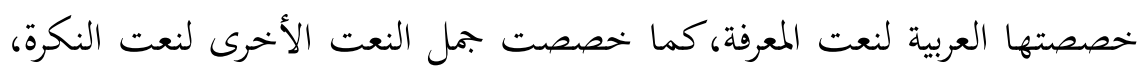

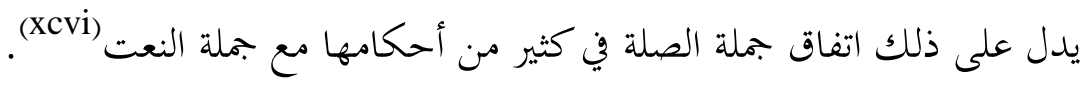
واشترط النحاة للنعت بالجملة ما يلي:

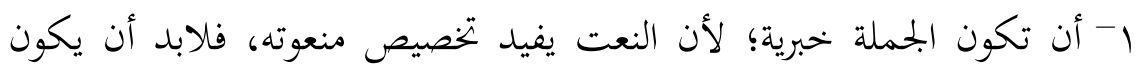

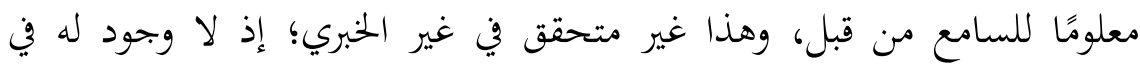

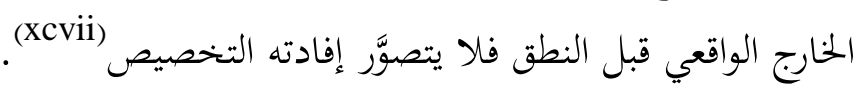

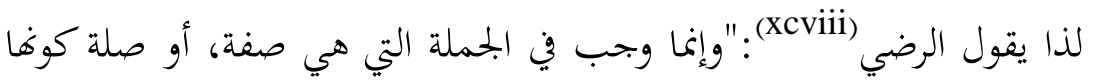

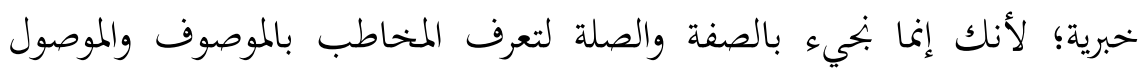


المبهمين بما كان المخاطب يعرفه قبل ذكرك الموصوف والموصول ، من اتصافها بمضمون الصفة والصلة إلا أن تكون الصفة والصلة جملتين متضمنتين للحكم المعلوم عند المخاطب حصوله قبل ذكر تلك الجملة، وهذه هي الخبرية؛ لأن غير الخبرية إما إنشائية، نحو: "بعت"، و و "طلقت و "أنت حر"، ونخوها ،وإما طلبية كالأمر والنهي والاستفهام والتمني والعرض، ولا لإل يعرف المخاطب أصول مضموغا إلا بعد ذكرهما" وفي هذا تنبيه إلى آداء الوظيفة الدلالية للموقع النحوي المعين، الذي يرتبط بصيغة الكلمات، أو العنصر اللغوي الذي يشغل هذا الموقع (بcix). r- أن تشتمل جملة النعت على رابط يربطها بالمنعوت؛ لأن النعت والمنعوت

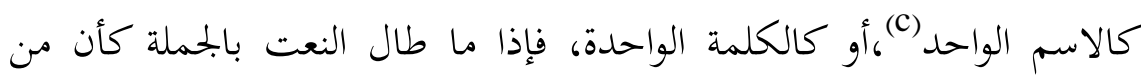
الازم ارتباطها بالمنعوت ، في ذلك يقول الرضي : على " إنما اشترط الضمير في الصفة والصلة يحصل به ربط بين الموصوف وصفته، والموصول وصلته ، فيحصل بذلك الربط اتصاف الموصوف والموصول بمضمون الصفة والصلة ، فيحصل لمما هذذا الاتصاف تخصص أو تعرف ، ولو قلت : " مررت برجل قام عمرو " لم يكن الرجل متصفاً بقيام عمرو بوجه ، فلا يتخصص به ، فإذا قلت: "قام عمرو في دارة"صار الرجل متصفاً بقيام عمرو في داره "(ci) . وللضمير الي يربط جملة النعت بالمنعوت دور في تحقق التماسك النصي

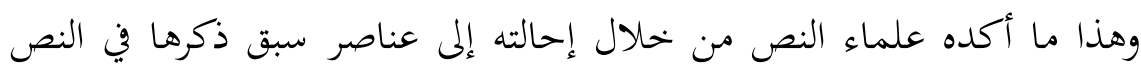
السابق ، فضلا عن أن الغرض من الربط هو الاختصار وأمن اللبس بالتكرار و إعادة الذكر ؛ فقي قولك :"هذا رجل قلبه رحيم".

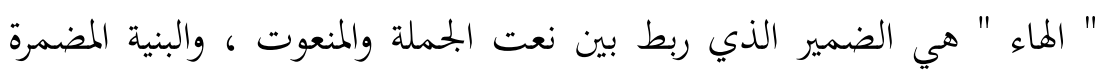
هنا هي : هذا رجل · قلب الرجل رحيم • فوجود الضمير يشير إلى تعلق الجملة 
الثانية بصاحب الضمير ، ولولا وجود الضمير لنشأ لبس في فهم الانفصال بين الجملتين ، ولأدى ذلك إلى لبس آخر في فهم أن " الرجل " في الجملة الثانية غير

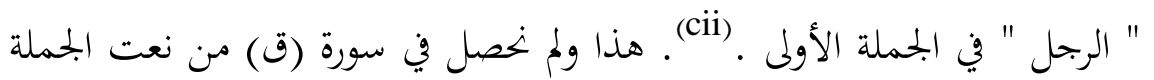
إلا على جملتين نُعت فيها النكرة بالجملة الاسمية من ذلك قوله تعالى(ciii) :

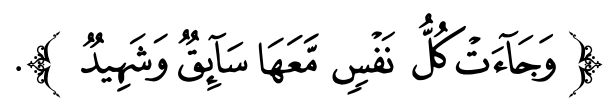
فالجملة الاسمية " معها سائق " صفة كل .

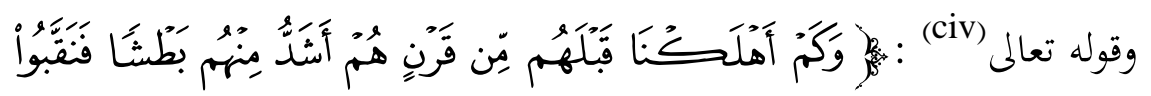

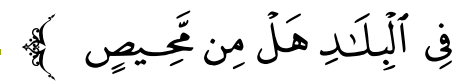

$$
\begin{aligned}
& \text { فجملة (هم أشدُّ) في محل جر نعت هُ لـ لـ (قرن). }
\end{aligned}
$$

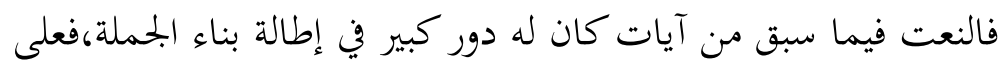

الرغم من كون النعت فضلة إلا أن المعنى يتطلب النعت بصورة لا يتم إلا به ،

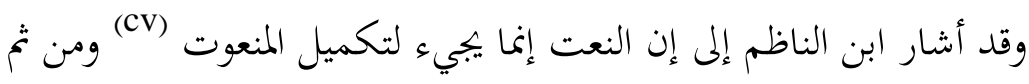

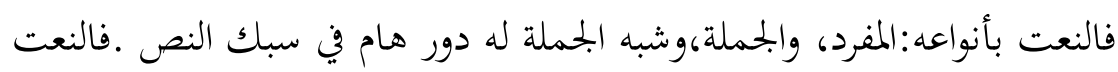
المفرد يقوم بالسبك عن طريق ارتباطه الشديد بالمنعوت، كما أنه للتعرف عل النعت لابد من الرجوع إلى المنعوت وذلك عن طريق الإحالة القبلية(cvi). وبذلك يقوم النعت بدور الترابط العضوي في التركيب؛هور وسيلة من وسائل التماسك النصي كما يقول المحدثون؛حيث إنَّ النعوت تدعم الأسماء في بـوني

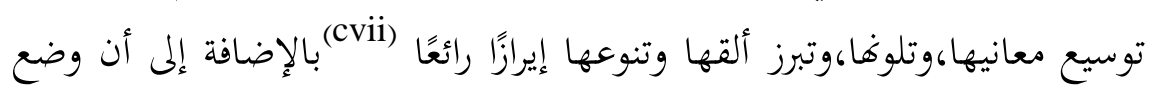
النعت في مكان هام ليس سوى طريقة أخرى لمنحه ثقلصا وقيمةوغدخال النعتفي تركيب الجملة والاتساع يحتاج دائمًا إلى الوصف الذي يعد النعت أحد أدواته،وإدخال النعت في تركيب الجملة والاتساعفيه صورة من صور التطور اللغوي 
وذلك ان الإنسان يمتاج إلى الوصف الذي يعد النعت أحد أدواته،وكلما تقدم به

$$
\text { العلم والفكر احتاج إلى استعماله. }
$$

وسورة (ق) إحدى سور القرآن التي اعتمدت على الوصف والاستطراد،فقد

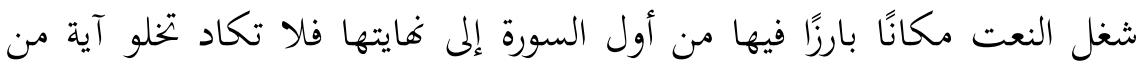
آياتما من النعت فقد بلغ عدد الآيات التي اشتملت على النعت بأنواعه المختلفة أربع وعشرون آية من بحمل آياتا البالغ خمسًا وأربعين آية. 


\section{حذف المنعوت}

ظاهرة حذف النعت من الظواهر اللغوية الأسلوبية المهمة التي تتصل بالتركيب النصي وتتولد هذه الظاهرة من خلال قرينة التضام أو التلازم بين عنصرين لغويين،ف"هو بابُ دقيق المسلك،لطيف المأخذ،عجيب الأمر،شبيه بالسحر، فإنك ترى به ترك الذكر ، أفصح من الذكر ، والصمت عن الإفادة أزيد

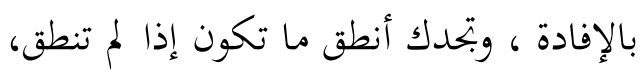

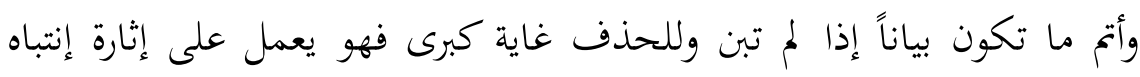

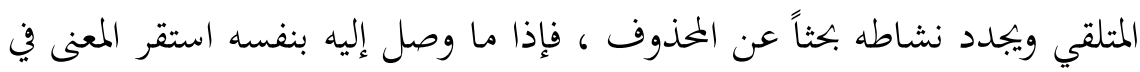
ذهنه .

فالحذف كما نفهم من النص السابق ظاهرة لغوية أسلوبية ، وقد اشترطوا

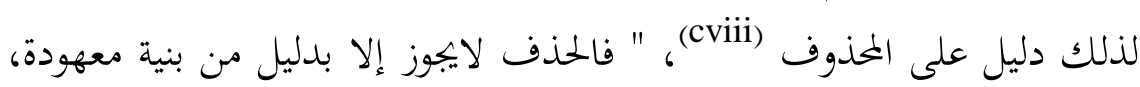

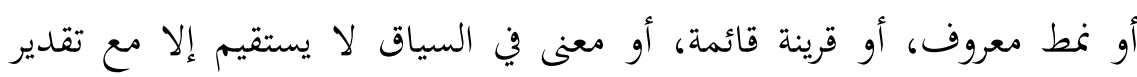
المحذوف.

إذا "فالحذف لا مفر من القول به ، إذا أردنا أن نفهم الاستعمال اللغوي على وجهه الصحيح؛ لأن للحذف من المبررات أموراً لا مناص من الاعتداد (cix)" (c)

وقد أجاز نحاتنا-رحمهم الله- حذف المنعوت بشرط أن يكون معلوماً من السياق ، أشار إلا ذلك الردي في شرحه على الكافية بقوله : " أعلم أن الن

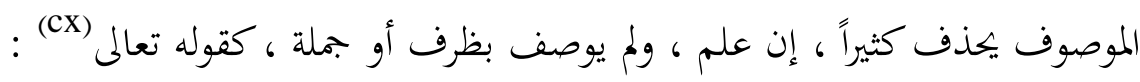

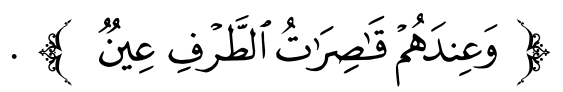
فإن وصف بأحدهم جاز كثيراً أيضاً بالشرط المذكور بعدُ . 


$$
\text { ويشترط الزركشي شرطين لحذف الموصوف : }
$$

أولمما : كون الصفة خاصة بالموصوف ؛ حتى يكصل العلم بالموصوف ؛

$$
\text { فمتى كانت امتنع حذف الموصوف . }
$$

الثاني : أن يعتمد على بحرد الصفة من حيث هي ، لتعلق عرض السياق،

$$
\text { كقوله تعالى (cxi) : }
$$

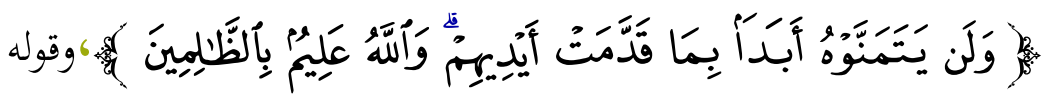

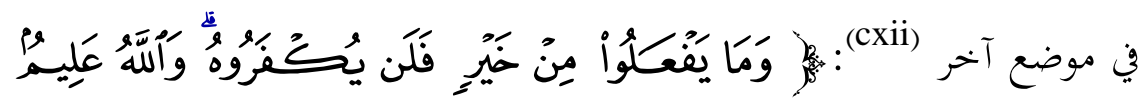

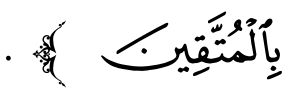

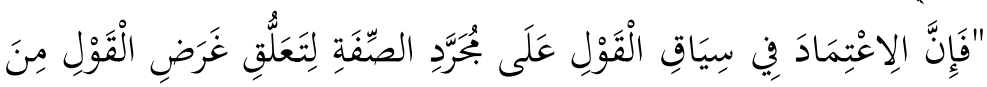

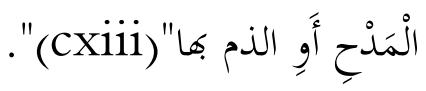

وقد عقد ابن جني لظاهرة الحذف بابًا في الخصائص سمَّاه(باب شجاعة العربية). ولأستاذنا الدكتور/أحمد كشك رأى في حذف المنعوت إذ إنه يرى أن "التنغيم قرينة مهمة من القرائن التي تعين على تحديد المنعوت المحذوف،ويدلل على

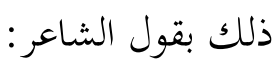

$$
\text { ترمي بكفي كان من أرمى البشر }
$$

إذ يقول:"إن تصورنا النطقي له لايرى مهربًا من إحكام الضغط على جملة

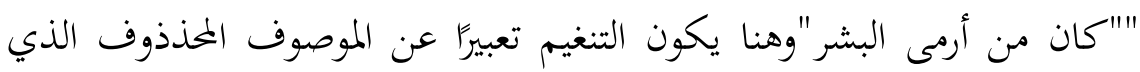

$$
\text { يساوي قوله:(هو بكفي رجلٌ كان من أرمى البشر). }
$$

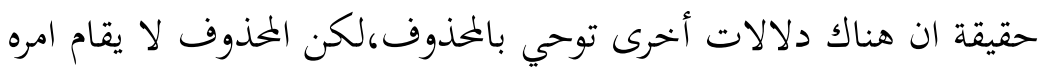
من خلال دلالة واحدة حيث تكتنفه وتخيط به وسائل كثيرة تميزه منها التنغيم (cxiv). 
وإذا انتقلنا إلى سورة (ق)وجدنا أن ظاهرة حذف المنعوت وإحلال

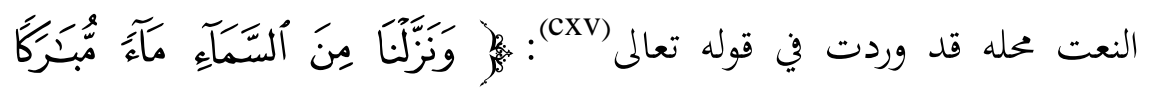

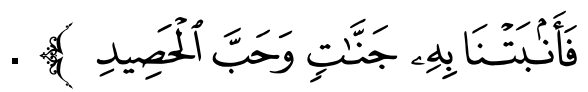
فـ (الحصيد) صفة للنبت،وقد نابت عنه،والتقدير:(وحب النبت الحصيد)،وحذف المنعوت في هذه الآية لم يكن خلوًا من الدلالة،فقد وقع الحذف لمن للمنعوت؛ لتتوفر العتاية على النعت؛وبذلك استُغني عن المنعوت الذي يتساوى

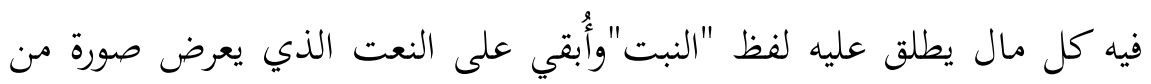
صور التدبر والتفكير ،وأنه إذا كان هؤلاء الكافرون الضالون ،قد كلَّت أبصارهم عن أن تصافح السماء ،وتقع على موقع العبرة والعظة منها ،وأن يعموا أو يتعاموا عن الأرض وما بين أيديهم من آيات الله منها - إذا كان هذا شأفم فيما في السماوات والأرض ،فهذا معرض من معارض النظر، ليس في السماء وإنما هو محسوس بين أيديهم وهو إحياء الله الأرض الهامدة فيخرج من بطنها هذه الحبات والزووع التي يجيا عليها ،ويعيش من ثمرها وحبها الإنسان. 


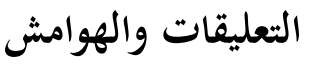

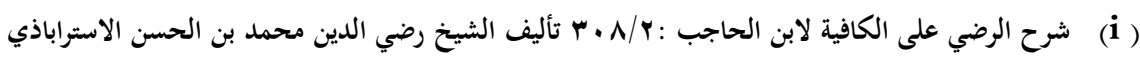

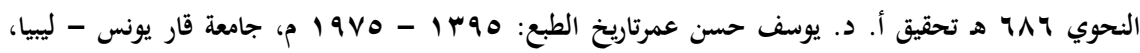

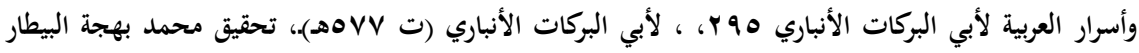
مطبوعات المجمع العلمي بدمشق، والأشباه والنظائر للسيوطي / / V لأبي عبد الرحمن بن أبي بكر، جلال الدين السيوطي (المتوفى: |19هـ) ، تحقيق الدكتور/ عبد العال سالم مكرم ، طبعة مؤسسة الرسالة - بيروت ،الطبعة:

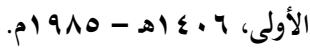

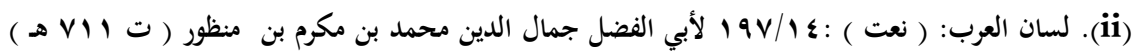

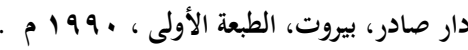
(iii) نتائج الفكر في النحو: 101 . لأبي القاسم عبد الرحمن بن عبد الله بن أحمد للسُهَهيلي (المتوفى: المهـ)، تحقيق : عادل أحمد عبد الموجود ، وعلي محمد معوض، طبعة دار الكتب العلمية - بيروت الطبعة الأولى: . $1994-1 \leqslant 15$

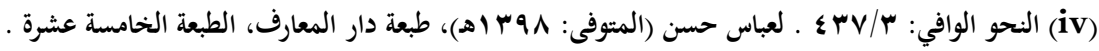

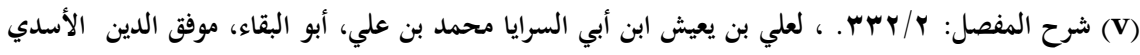
الموصلي، المعروف بابن يعيش وبابن الصانع (المتوفى: بـ †هـ) ،قدم له: الدكتور إميل بديع يعقوب طبعة دار

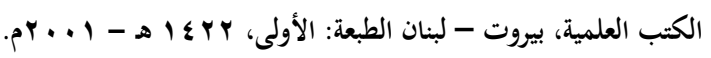
(vi) حاشية الصبان على شرح الأشموني: / / ه ه ، تحقيق مصطفى حسين أحمد، مطبعة الاستقامة ، القاهرة ، ط

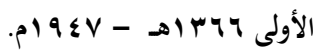

(vii)

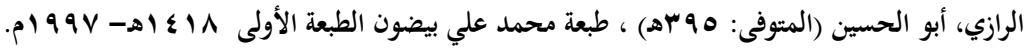
(viii) 


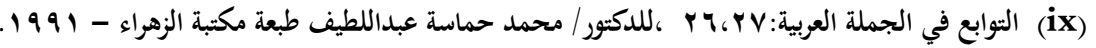
التركيب النعتي في العربية : ج4 1 .د/ السيد علي خضر .مجلة كلية الآداب - جامعة المنصورة .العدد السابع

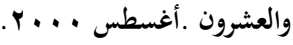

(xi) (xii)

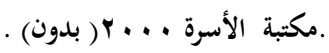

(xiii) علم اللغة بين النظرية والنطبيق دراسة تطبيقة على السور المكية: 1/91 . د/ صبحي إبراهيم الفقي دار قباء القاهرة، وانظر بلاغة الخطاب وعلم النص ؟بץ ـد/صلاح فضل المجلس الوطني للثقافة. (xiv)

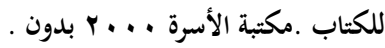

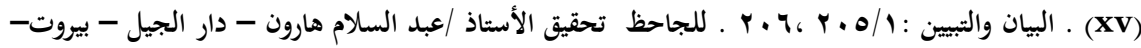
لبنان بدون تاريخ ورقم طبعة. (Xvi)

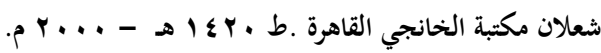
r... ، السابق : (xvii) (xviii) (xix) . نحو أجرومية للنص الشعري ،ودراسة في قصيدة جاهلية: ع 1 اد/سعد مصلوح بحث مجلة فصول المجلد . 1 ا العددان الأول والثاني يوليو واغسطس ب 99 ام. (XX) النص والخطاب والاتصال : به. للدكتور / محمد العبد، طبعة الأكاديمية الحديثة للكتاب الجامعي ط ؟ ، 


\section{سورة ق الآية: Xxi)}

سورة النساء من الآية :11 (Xxii)

(Xxiii)

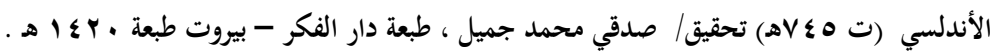
بناء الجملة العربية : عxiv) الكتاب : / / / Y Y تحقيق الأستاذ عبد السلام هارون.

$$
\text { شرح المفصل:Txvi) }
$$

اللمع في العربية : YXXii)

$$
\text { طبعة دار الكتب الثقافية - الكويت. }
$$

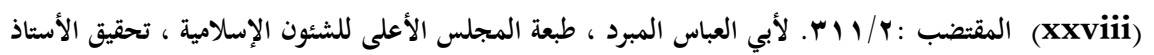

$$
\text { | عبد الخالق عضيمة. }
$$

سورة الشعراء الآية : 17 (Xxix)

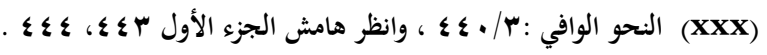

$$
\begin{aligned}
& \text { سورة النمل من الآية :هxxi) } \\
& \text { سورة الماعونالآيات : ع، - Vxxii) } \\
& \text { النحو الوافي ب/ (Xxxiii) } \\
& \text { (xxxiv) }
\end{aligned}
$$

همع الهوامع شرح جمع الجوامع في علم العربية / / إ 1 ، لجلال الدين السيوطي ، بتصحيح السيد (XXXV) محمد بدر الدين ـ مكتبة الكليات الأزهرية ، الطبعة الأولى، ب I I هـ .

$$
\text { r سورة البقرة من الآية: XXXvi) }
$$$$
\text { سورة آل عمران من الآية : ع 1. }
$$ 
سورة النساء من الآية : VN.XXXiii)

سورة التوبة من الآية: هץ.XXXix)

(Xl) سورة يوسف من الآية: (Xl)

(1)سورة الأعراف من الآية : . 11)

سورة البقرة من الآية : هlii)

همع الهوامع : (xliii)

(19 البحر المحيط / (xliv)

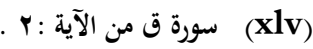

r: سورة ق من الآية (xlvi)

البحر المحيط: تفسير سورة ق . (xlvii)

ه سورة ق من الآية (xlviii)

سورة ق الآية : ع (xlix)

9: سورة ق من الآية (1)

(li)

سورة ق من الآية : 11ii)

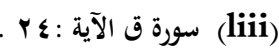

سورة ق الآية : (liv)

سورة ق الآية : جr (lv)

rv: سورة ق من الآية (lvi)

سورة ق الآية :Ylvii)

سورة ق الآية :rviii) 
. (lix)

$$
\text { سورة ق من الآية : ع ـ ـ (1x) }
$$

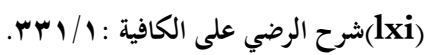

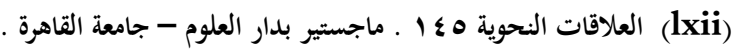

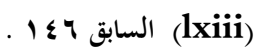

سورة ق الآية : llxiv)

(lXv)

11: سورة ق من الآية (lxvi)

(lxvii)

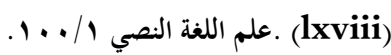

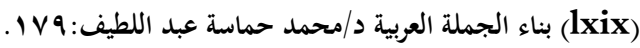

شرح المفصل لابن يعيش ؟ ؟ ا (lxxi)

شرح التسهيل r/xxii)

(lxxiii)

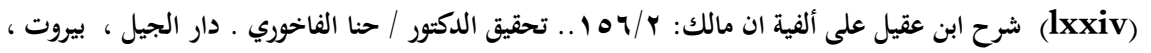
الطبعة الثانية، و9 9 (م.

(lxxv) ابن مالك الطائي الجياني، أبو عبد الله، جمال الدين (المتوفى: YTVA ، تحقيق د. عبد الرحمن السيد، د. محمد بدوي المختون طبعة هجر للطباعة والنشر والثوزيع والإعلان الطبعة: الأولى (• (1 اهـ - ـ99 (م). (1xxvi) 
سورة نوح الآية: · r lXxvii)

سورة طه الآية: 1Xxviii)

سورة ق الآية: 1 . (lxxix)

9. التوابع في الجملة العربية (1xxx)

179 : الشعراء من الآية (lxxxi)

التوابع أصولها وأحكامها : ب9 ـ ـ للدكتور / فوزي مسعود الطبعة الأولى ع 9 ام (lxxxii)

السابق : الم : lxxxiii)

(lxxxiv)

التوابع في لغة القرآن د / السيد محمود جامع : ه ـ دكتوراه بكلية دار العلوم بالقاهرة، به9xxv)

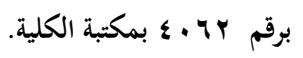
التوابع في الصحيحين دكتوراه بدار العلوم. (lxxxvi)

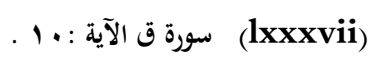

سورة ق من الآية :11xxxviii) سورة ق الآية : ؟ ب إlxxix) YO: مورة ق الآية

النكرة المحضة هي التي تخلو من ( أل الجنسية ) ومن كل شيء آخر يخصص ويقلل الشيوع ؛ كالإضافة، والنعت وسائر القيود الني تفيد التخصيص. أما النكرة غير المحضة فهي التي لم تتخلص مما سبق ؛ بأن يكون المنعوت مشتملاً على "أل الجنسية " التي تجعل لفظه معرفة ، ومعناه نكرة. (Ycii)

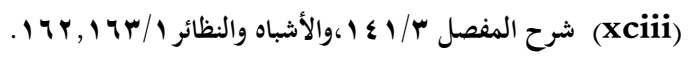


(Xciv)

$$
\text { للكتاب الطبعة الرابعة. }
$$

$$
\text { شرح المفصل// XCV) }
$$

199/1919 نوام الارتباط والربط في تركيب الجملة العربية (Xcvi) التوابع بين القاعدة والحكمةه (Xcvii)

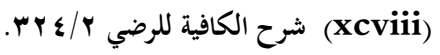
التوابع بين القاعدة والحكمة 7 (Xcix)

$$
\text { . الكتاب / (c) }
$$

$$
\text { (ci) شرح الرضي على الكافية: ب/ (ci) }
$$

نظام الارتباط والربط في تركيب الجملة العربية : (cii)

$$
\begin{aligned}
& \text { Yl: سورة ق الآية (ciii) } \\
& \text { rq سورة ق الآية (civ) }
\end{aligned}
$$

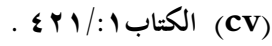

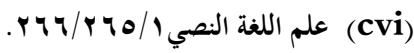

$$
\begin{aligned}
& \text { (Cvii) } \\
& \text { (Cviii) }
\end{aligned}
$$

(cix)

. 1994

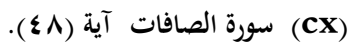

$$
\text { 90: سورة البقرة من الآية (Cxi) }
$$

سورة آل عمران آية :110 (Cxii) 
(Cxiii)

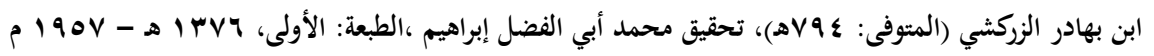
، دار إحياء الكتب العربية عيسى البابى الحلبي وشركائه. (Cxiv) . سورة البقرة الآية: (CXv) 


\section{فهرست المراجع}

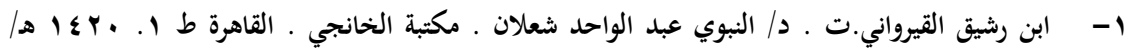

\section{...}

Y- أسرار العربية، لأبي البركات الأنباري (ت هVVV)..)، تحقيق محمد بهجة البيطار مطبوعات المجمع العلمي

\section{بدمشق.}

r- الأشباه والنظائر لأبي عبد الرحمن بن أبي بكر، جلال الدين السيوطي (المتوفى: 119ه) ، تحقيق الدكتور /

عبد العال سالم مكرم ، طبعة مؤسسة الرسالة - بيروت ،الطبعة: الأولى، 7 • ـ اهـ - ه19 ام.

ع - البحر المحيط في التفسير، لأبي حيان محمد بن يوسف بن علي بن يوسف بن حيان أثير الدين الأندلسي

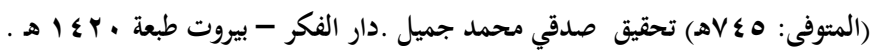

ه- - البرهان في علوم القرآن للزركشي ،أبي عبد الله بدر الدين محمد بن عبد الله بن بهادر الزركشي (المتوفى: ع 9.

$$
\text { العربية عيسى البابى الحلبي وشركائه. }
$$

צ- بلاغة الخطاب وعلم النص ،د/صلاح فضل، المجلس الوطني للثقافة.

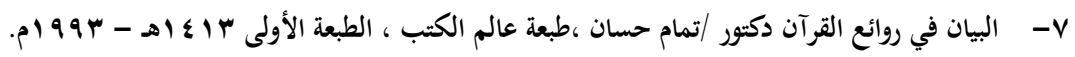

1- البيان والتبيين للجاحظ عبد السلام هارون - دار الجيل - بيروت - لبنان ـبدون تاريخ ورقم طبعة.

9- التركيب النعتي في العربية 17 ـ ـد/ السيد علي خضر .مجلة كلية الآداب جامعة المنصورة .العدد السابع

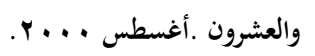

. 1 - التوابع أصولها وأحكامها للدكتور / فوزي مسعود الطبعة الأولى ع 91 ام .

1ا - التوابع بين القاعدة والحكمة للدكتور / محمود عبد السلام شرف الدين، هجر للطباعة ا، الطبعة الأولى

$$
\text { . } 19 \wedge V-\rightarrow 1 \leq \cdot V
$$


r ا - التوابع بين القاعدة والحكمة للدكتور /محمود عبد السلام شرف الدين طبعة هجر للطباعة ، القاهرة ، الطبعة

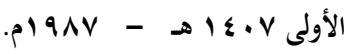

با - التوابع في الجملة العربية للدكتور / محمد حماسة عبداللطيف طبعة مكتبة الزهراء - 199 ام. ع ا- التوابع في الصحيحين دراسة نحوية، ماجستير لمحمد حماد صابر محمد، كلية دار العلوم . القاهرة

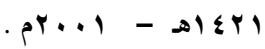

ه - التوابع في لغة القرآن د / السيد محمود جامع د دكتوراه بكلية دار العلوم بالقاهرة، ب191 م . برقم

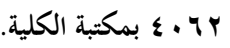

17

$$
\text { p) } 9 \leq V-\text { - Dו1 }
$$

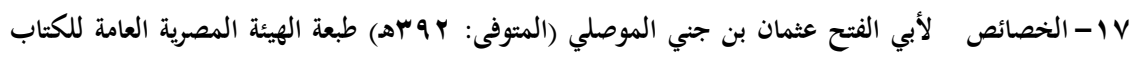

$$
\text { الطبعة الرابعة. }
$$

1 ا- دلائل الإعجاز لعبد القاهر الجرجاني. ت محمود محمد شاكر . الهيئة المصرية العامة للكتاب .مكتبة

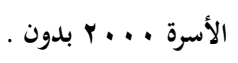

9 1 - شرح ابن عقيل على ألفية ان مالك ـ تحقيق الدكتور / حنا الفاخوري ـ دار الجيل ، بيروت ، الطبعة الثانية ،

$$
\text { . १९9V }
$$

• • - شرح الرضي على الكافية لابن الحاجب تأليف الشيخ رضي الدين محمد بن الحسن الاستراباذي النحوي

$$
\text { \ه }
$$

ا Y- شرح المفصل لابن يعيش بن علي بن يعيش ابن أبي السرايا محمد بن علي، أبو البقاء، موفق الدين الأسدي الموصلي، المعروف بابن يعيش وبابن الصانع (المتوفى: بـ جهـ) ،قدم له: الدكتور إميل بديع يعقوب طبعة

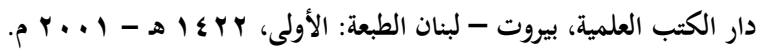

$$
\begin{aligned}
& \text { r Y - شرح المفصل لموفق الدين ابن يعيش ، عالم الكتب ، بيروت. }
\end{aligned}
$$


بr- شرح تسهيل الفوائد لمحمد بن عبد الله، ابن مالك الطائي الجياني، أبو عبد الله، جمال الدين (المتوفى:

Y Y Tهـ، تحقيق د. عبد الرحمن السيد، د. محمد بدوي المختون طبعة هجر للطباعة والنشر ، الطبعة:

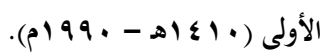

ع ץ - الصاحبي في فقه اللغة العربية ومسائلها وسنن العرب في كلامها لأأحمد بن فارس بن زكرياء القزويني الرازي،

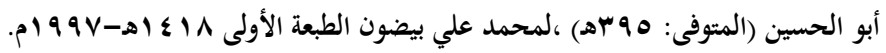
هץ - العلاقات النحوية . ماجستير بدار العلوم - جامعة القاهرة . צץ - علم اللغة النصي بين النظرية والتطبيق دراسة تطبيقية على السور المكية .

$$
\text { د صبحي إبراهيم الفقي دار قباء القاهرة. }
$$

VV - العمدة في محاسن الشعر وآدابه ونقده لابن رشيق القيرواني ت. د/ النبوي عبد الواحد شعلان مكتبة

$$
\text { ^r - الكتاب لسيبويه تحقيق الأستاذ عبد السلام هارون. }
$$

q 9 - لسان العرب لأبي الفضل جمال الدين محمد بن مكرم بن منظور ( ت VII هـ) دار صادر، بيروت ،

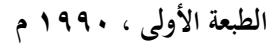

• ب- اللغة وبناء الشعر للدكتور/محمد حماسة طبعة مكتبة الزهراء ، 1 شارع عبد العزيز ـ عابدين القاهرة -

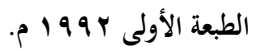

اب- اللمع في العربية ، لأبي الفتح عثمان بن جني الموصلي (المتوفى: r جهـ) ، تحقيق فائز فارس ،طبعة دار

$$
\text { الكتب الثقافية - الكويت. }
$$

r r- المقتضب لأبي العباس المبرد ، طبعة المجلس الأعلى للشئون الإسلامية ، تحقيق الأستاذ / عبد الخالق

$$
\text { عضيمة. }
$$

بr- من وظائف الصوت اللغوي ، محاولة لفهم صرقي ،ونحوي ، ودلالي للدكتور / أحمد كثك طبعة دارللطباعة

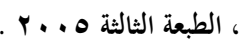


§ ب- - نتائج الفكر في النحو الكتاب: نتائج الفكر في النَّحو لأبي القاسم عبد الرحمن بن عبد الله بن أحمد للسُّهَيلي (المتوفى: 10Nه)، تحقيق : عادل أحمد عبد الموجود ، وعلي محمد معوض، طبعة دار الكتب

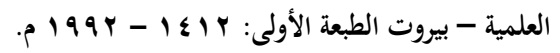

هـ- نحو أجرومية للنص الشعري ،دراسة في قصيدة جاهلية .د/سعد مصلوح بحث مجلة فصول المجلد . 1.

$$
\text { العددان الأول والثاني يوليو وأغسطس ب 99 ام. }
$$

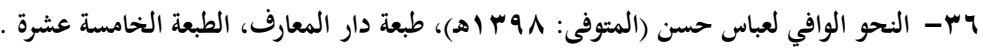

V V النص والخطاب والاتصال للدكتور / محمد العبد، طبعة الأكاديمية الحديثة للكتاب الجامعي ط ب ،

$$
\text { P. I }
$$

^ז- نظام الارتباط والربط في تركيب الجملة العربية للكتور / مصطفى حميدة ، مكتبة لبنان الشركة المصرية

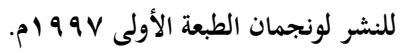

q ب- همع الهوامع شرح جمع الجوامع في علم العربية ، لجلال الدين السيوطي ، بتصحيح السيد محمد بدر الدين ـ مكتبة الكليات الأزهرية ، الطبعة الأولى، TV I I هـ . 